\title{
Trophic interactions between the Patagonian toothfish, its fishery, and seals and seabirds around Macquarie Island
}

\author{
S. D. Goldsworthy ${ }^{1, *}$, X. He ${ }^{1}$, G. N. Tuck ${ }^{1}$, M. Lewis ${ }^{1}$, R. Williams ${ }^{2}$ \\ ${ }^{1}$ CSIRO Marine Research, GPO Box 1538, Hobart, Tasmania 7001, Australia \\ ${ }^{2}$ Australian Antarctic Division, Channel Highway, Kingston, Tasmania 7050, Australia
}

\begin{abstract}
Macquarie Island is a small subantarctic island that supports a variety of breeding seabird and marine mammal populations. A fishery targeting the Patagonian toothfish Dissostichus elegenoides was established around the island in 1994. For ecological sustainable development (ESD) of the fishery, this study investigated the trophic interactions based on diet composition and annual consumption between Patagonian toothfish, its fishery, and seals and seabirds within the Macquarie Island Exclusive Economic Zone (MI-EEZ). Annual consumption rates for each predator were estimated from dietary data (mostly published sources), energetic budgets, prey energy content, and population size. Results indicated little predation on toothfish by seals or seabirds, or prey competition between toothfish and other marine predators. The greatest dietary overlap with toothfish was with gentoo penguins (21\% dietary overlap) and southern elephant seals (19\%). These overlaps in diet were small relative to those among fur seals ( 3 species, $\geq 90 \%$ ), giant petrels (84\%), royal and rockhopper penguins (65\%), and king and royal penguins and fur seals (>60\%). The total annual prey biomass consumed by seabirds, seals, toothfish and the fishery within the MI-EEZ was estimated to be $419774 \mathrm{t}$, with the greatest consumption in January, at $2779 \mathrm{t} \mathrm{d}^{-1}$. Pelagic fish $(61 \%$, mostly myctophids), followed by pelagic crustaceans (28\%, mostly euphausids) and cephalopods $(7 \%)$ were the major prey. Most prey biomass was consumed by penguins ( $88 \%)$, with comparatively small amounts by toothfish $(8 \%)$, seals $(3 \%)$ other seabirds $(<1 \%)$ and the fishery $(0.1 \%)$. These results indicate weak trophic linkages between the toothfish, its fishery, and seabirds and seals around Macquarie Island.
\end{abstract}

KEY WORDS: Patagonian toothfish · Seabirds · Seals · Dietary overlap · Trophic interactions · Prey consumption · Commercial fisheries · Macquarie Island

\section{INTRODUCTION}

With major decreases in many of the world's fish stocks over the last few decades, and the concomitant development of more intensive fishing methods, there has been increased interest in the extent of competition for fish stocks between commercial fisheries and

\footnotetext{
*Present address: Zoology Department, La Trobe University, Victoria 3086, Australia.

E-mail: s.goldsworthy@zoo.latrobe.edu.au
}

seabirds and marine mammals. Early investigations into this competition were aimed at assessing the extent to which seals and seabirds consumed fishes that could have potentially provided economic benefit to commercial fisheries (Davies 1958, Matthews 1961, Furness \& Cooper 1982, Furness 1984). Many of these studies suggested that some seal and seabird populations consumed large quantities of commercially important fish species, and such information has been used to justify reductions in seal and seabird numbers (Davies 1958, Butterworth et al. 1988). More recently, 
with greater efforts to manage fisheries under the principles of Ecological Sustainable Development (ESD), the focus of studies has changed to examine how commercial fishing may effect the conservation status of seabird and marine mammal populations. Some research has suggested that commercial fisheries may be significant competitors with seabirds and marine mammals (Furness \& Cooper 1982, Duffy 1983, Hammill et al. 1997, Stenson et al. 1997, Trites et al. 1997), and, in cases of overfishing, cause major decreases in their populations (Anderson \& Gress 1984, Burger \& Cooper 1984).

The recent rapid expansion of the Patagonian toothfish Dissostichus eleginoides (hereafter toothfish) commercial fishery in the Southern Ocean, has raised concerns over the sustainability of the fishery. In addition, the ecological consequences of overfishing, especially on populations of seabirds and marine mammals, is unclear. The dependence of sea birds and marine mammal populations (primarily seals) on marine resources in Southern Ocean and Antarctic waters has been assessed by a number of studies, and some have also estimated the potential competition and impacts that commercial fisheries (mostly for Antarctic krill Euphausia superba) may have on their populations (Croxall \& Prince 1982, Croxall et al. 1984, 1985, Abrams 1985, Hunt 1985, Brown 1989, Woehler \& Green 1992, Adams et al. 1993, Guinet et al. 1996, Ichii et al. 1996, Croll \& Tershy 1998, Green et al. 1998, Moore et al. 1998). Studies investigating the consumption of marine resources by seals and seabirds in the South Atlantic Ocean have generally shown the importance of Antarctic krill in these food webs (Croxall \& Prince 1982, Croxall et al. 1984, 1985, Croll \& Tershy 1998). However, in subantarctic regions of the South Indian and Pacific Oceans, fishes appear to be more important prey than pelagic crustaceans, as such commercial finfisheries (e.g. toothfish, marbled rockcod Notothenia rossii and mackerel icefish Champsocephalus gunnari) may place seabirds and seals at greater risk of competition for foods (Woehler \& Green 1992, Adams et al. 1993, Guinet et al. 1996, Green et al. 1998, Moore et al. 1998).

At Macquarie Island $\left(54^{\circ} 30^{\prime} \mathrm{S}, 158^{\circ} 55^{\prime} \mathrm{E}\right)$ in the South Pacific Ocean, a commercial fishery for toothfish was developed in 1994, and was the first commercial fishery for the region. Current management of the fishery by the Australian Fisheries Management Agency restricts fishing to trawling and to one single vessel in total. Other licensing conditions include the carriage of 2 observers on each fishing voyage to collect scientific data on the fishery, and to monitor environmental impacts. The discharge of factory waste that may attract and provision birds and seals is also prohibited. The fishing season extends from 1 September to 31
August, with most fishing occurring between October and February. To date there has been no illegal or unreported fishing around the island. The average annual catch of toothfish between 1996/97 and 1998/99 was $550 \mathrm{t}$.

Macquarie Island is an important breeding site for large numbers of land-breeding marine predators, including 86000 seals and over 3 million seabirds, most of which are penguins. In line with development and management of the fishery under the principles of ESD, it is essential to understand the potential interactions among the fishery, the toothfish population, and other marine predators such as seabirds and seals. This study aims to examine the trophic interactions based on the diet composition and relative consumption rates between the fishery, toothfish, seabirds and seals around Macquarie Island. Dietary overlaps among predators were estimated and used to assess potential food competition among predators. Annual consumption rates on all prey by these predators were also estimated and compared. These estimates will provide useful information for assessing the relative importance of toothfish in the Macquarie Island ecosystem, and can be used to assess potential interactions between the toothfish fishery and other marine predators.

\section{METHODS}

Area and species in study. Macquarie Island is a small (12785 ha) subantarctic island approximately $1500 \mathrm{~km}$ south-east of Tasmania, Australia (Fig. 1). The Macquarie Island Exclusive Economic Zone (MI-EEZ) extends from 3 to 200 nautical miles (5.6 to $370 \mathrm{~km}$ ) from the island. The north-eastern edge of the MI-EEZ is slightly less than $370 \mathrm{~km}$, where it joins the Campbell and Auckland Islands EEZ (New Zealand, Fig.1). The area of ocean within the MI-EEZ is approximately $415600 \mathrm{~km}^{2}$. Only those species that undertake a significant portion of their foraging within the MI-EEZ, or have substantial biomass, were included in this study. These include the king Apenodytes patagonicus, royal Eudyptes schlegeli, and rockhopper E. chrysocome penguins, southern elephant seal Mirounga leonina and Antarctic Arctocephalus gazella and New Zealand A. forsteri fur seal, black-browed albatross Diomedea melanophrys, northern Macronectes halli and southern M. giganteus giant petrel and Antarctic prion Pachyptila desolata, which are present in the vicinity of the island during the breeding and moulting periods. Gentoo penguins Pygoscelis papua and Macquarie shags Phalacrocorax purpurascens, are resident year-round, while the subantarctic fur seal A. tropicalis is present on the island from December to October. Toothfish were also assumed to be resident. 


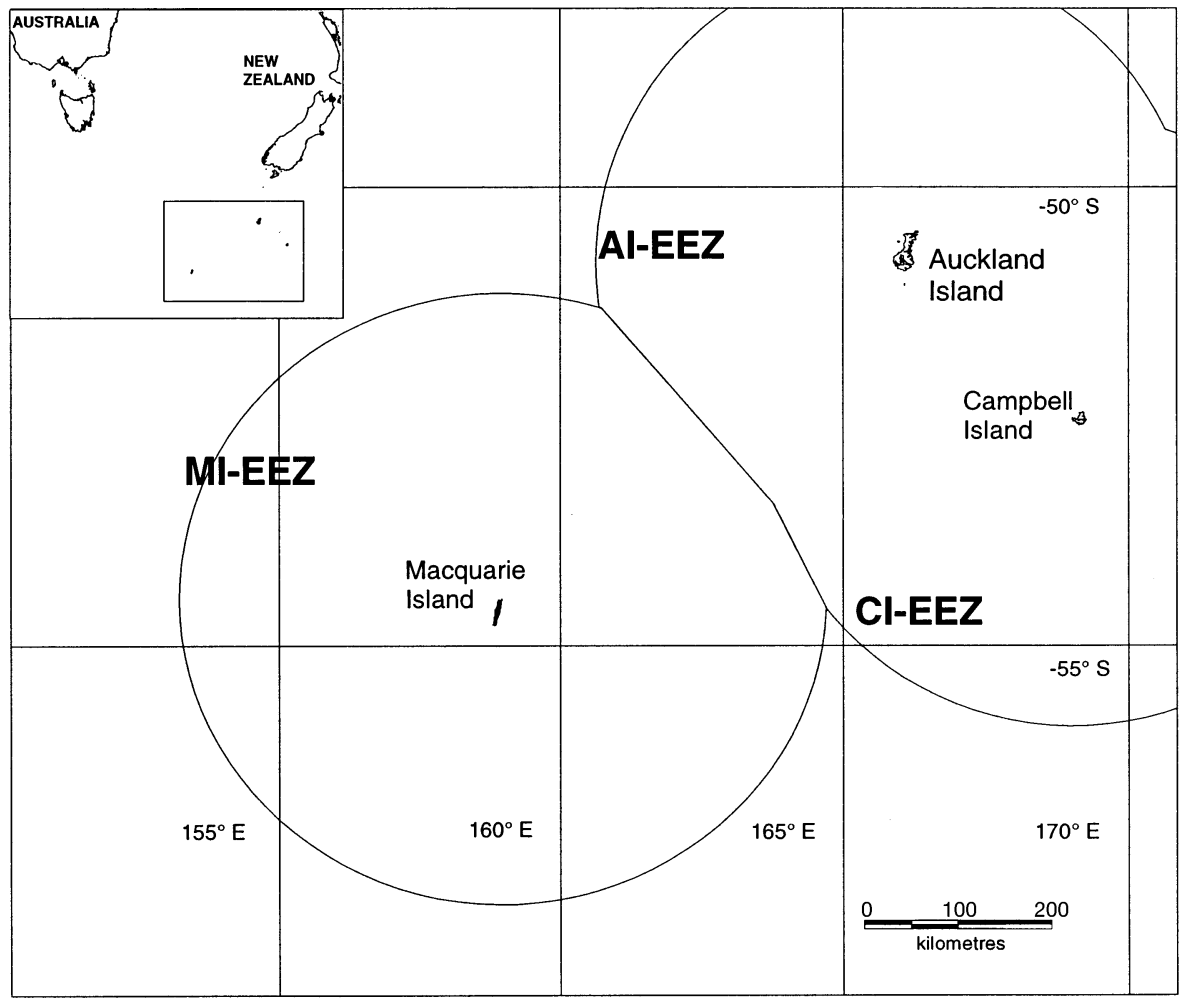

Fig. 1. Location of Macquarie Island and the Macquarie Island Exclusive Economic Zone (MIEEZ) relative to Campbell (CI) and Auckland (AI) Islands' EEZs
Species, such as several of the small and large petrels that mostly forage outside the MI-EEZ (sooty shearwaters Puffinus griseus; white-headed petrel Pterodroma lessonii; blue petrel Halobaena caerulea; light-mantled sooty albatross Phoebetria palpebrata; grey-headed albatross Diomedea chrysostoma; and wandering albatross $D$. exulans), other seabirds with very low abundance and biomass (fairy prion Pachyptila turtur; common diving petrel Pelecanoides urinatrix; South Georgian diving petrel P. georgicus; and Wilson's storm petrel Oceanites oceanicus), and species that feed mostly along the shoreline and inland (Antarctic terns Sterna vittata; kelp gulls Larus dominicanus; and subantarctic skua Catharacta lonnbergi), were omitted from the study. Because of paucity of data, cetaceans were also excluded.

Population and biomass estimates. The population and biomass estimates of seabirds and seals at Macquarie Island used in this study are presented in Table 1. Population estimates for the southern elephant seal at Macquarie Island were based on an estimated annual pup production of 20000 (D. Slip, Environment Australia, pers. comm.) and age-specific survival-rate data from Heard Island and South Georgia (McCann 1985, Slip 1997). The biomass of each age class was estimated from the product of the number of individuals in an age class and their mean mass (Slip 1997). For fur seals, population and biomass estimates were based on pup production and mass data (Goldsworthy et al. 1998, Goldsworthy unpubl. data), and hypothetical agespecific survival rates based on Antarctic and northern Callorhinus ursinus fur seal populations (York 1987, Boyd et al. 1995).

For king penguins, population estimates were based on data from D. E. Rounsevell (unpubl. data in Scott 1994) extrapolated through to 1999 based on annual increases in chick production of 5 to $15 \%$, the probable range of population growth based on other populations (E. J. Woehler pers. comm.). A mean growth rate of $10 \% \mathrm{yr}^{-1}$ was used to calculate the population estimate in this study. Adult population size (individuals) was estimated by multiplying chick production by 3 (i.e. adult population $=$ chick production $\times 2$ [adults] $\times 1.5$ [average of 2 chicks per $3 \mathrm{yr}$ ]). For royal, rockhopper, and gentoo penguins, population estimates were based on Warham (1963), Rounsevell \& Brothers (1984), Copson \& Rounsevell (1987), G. R. Copson (in Scott 1994), and Robinson \& Hindell (1996). Biomass estimates for penguins were calculated by multiplying population size by average adult masses (Barrat 1976, Reilly \& Kerle 1981, Green \& Gales 1990, Hull 1997).

Estimates of the population size of black-browed albatrosses, southern and northern giant petrels and Antarctic prions were derived from Johnstone (1977), Brothers (1984) and Robinson \& Scott (1999). Average mass data for these species were obtained from 
Table 1. Population and biomass estimates, mean individual mass, metabolic rates and estimated annual days and energy used for 13 marine predators in the Macquarie Island EEZ. Sources of data and estimates are given in second subsection of 'Methods'. M: male; F: female; Juv: juvenile; AM: adult male; SAM: sub-adult males; FMR: field metabolic rate; ME: metabolic energy; ER: energy requirements; ind.: individual $;$-: no data

\begin{tabular}{|c|c|c|c|c|c|c|c|c|c|c|}
\hline & $\begin{array}{l}\text { Estimated } \\
\text { population es } \\
\text { range }\end{array}$ & $\begin{array}{l}\text { Population } \\
\text { esitimate used } \\
\text { (ind.) }\end{array}$ & $\begin{array}{l}\text { Estimated } \\
\text { biomass } \\
\text { (t) }\end{array}$ & $\begin{array}{l}\text { Sex } \\
\text { age } \\
\text { class }\end{array}$ & $\begin{array}{l}\text { Mean } \\
\text { ind } \\
\text { mass } \\
(\mathrm{kg})\end{array}$ & $\begin{array}{c}\text { FMR } \\
\text { sea } \\
\left(\mathrm{kJ} \mathrm{d}^{-1}\right)\end{array}$ & $\begin{array}{c}\text { FMR } \\
\text { shore } \\
\left(\mathrm{kJ} \mathrm{d}^{-1}\right)\end{array}$ & $\begin{array}{l}\text { Days } \\
\text { in } \\
\text { EEZ }\end{array}$ & $\mathrm{ME}$ & $\begin{array}{l}\text { Annual } \\
\text { ER from } \\
\text { EEZ } \\
\text { (MJ) }\end{array}$ \\
\hline Southern elephant seal & $20000^{\mathrm{a}}$ & 86150 & 39283 & & & & & 14 & & 809 \\
\hline \multirow[t]{4}{*}{ Antarctic fur seal } & $106^{a}$ & 457 & 15 & M & 140.0 & 76689 & 59996 & 75 & 0.74 & 5949 \\
\hline & & & & $\mathrm{F}$ & 33.8 & 33411 & 14483 & 134 & 0.74 & 3847 \\
\hline & & & & SAM & 65.0 & 35605 & 27855 & 90 & 0.74 & 3266 \\
\hline & & & & Juv & 16.0 & 8810 & 6892 & 90 & 0.74 & 808 \\
\hline \multirow[t]{4}{*}{ Subantarctic fur seal } & $30^{\mathrm{a}}$ & 129 & 4 & $\mathrm{M}$ & 140.0 & 76689 & 59996 & 75 & 0.74 & 5949 \\
\hline & & & & $\mathrm{F}$ & 33.8 & 33411 & 14483 & 319 & 0.74 & 9066 \\
\hline & & & & SAM & 65.0 & 35605 & 27855 & 90 & 0.74 & 3266 \\
\hline & & & & Juv & 16.0 & 8810 & 6892 & 90 & 0.74 & 808 \\
\hline New Zealand fur seal & $2-3000^{\mathrm{b}}$ & 2500 & 150 & AM-Juv & 60.0 & 32867 & 25713 & 49 & 0.74 & 1634 \\
\hline \multirow[t]{2}{*}{ King penguin } & $131863-299019^{\mathrm{c}}$ & 323162 & 3926 & $\mathrm{M}$ & 12.8 & 7860 & 3499 & 237 & 0.74 & 1816 \\
\hline & & & & $\mathrm{F}$ & 11.5 & 7275 & 3256 & 247 & 0.74 & 1704 \\
\hline \multirow[t]{2}{*}{ Royal penguin } & $850000^{c}$ & 1700000 & 9435 & $\mathrm{M}$ & 5.7 & 4035 & 1883 & 216 & 0.74 & 776 \\
\hline & & & & $\mathrm{F}$ & 5.4 & 4035 & 1883 & 214 & 0.74 & 776 \\
\hline \multirow[t]{2}{*}{ Rockhopper penguin } & $100000-500000^{\mathrm{c}}$ & 600000 & 2190 & $\mathrm{M}$ & 3.6 & 2843 & 1360 & 199 & 0.74 & 437 \\
\hline & & & & $\mathrm{F}$ & 3.7 & 2843 & 1360 & 208 & 0.74 & 458 \\
\hline \multirow[t]{2}{*}{ Gentoo penguin } & $4700-6800^{\mathrm{c}}$ & 11500 & 66 & Breeding & 5.7 & 4383 & 2033 & 150 & 0.74 & 574 \\
\hline & & & & Winter & 5.7 & 4383 & 2033 & 215 & 0.74 & 804 \\
\hline Black-browed albatross & $180^{\mathrm{C}}$ & 360 & 1 & Adults & 3.7 & 2500 & 945 & 225 & 0.69 & 490 \\
\hline \multirow[t]{2}{*}{ Northern giant petrel } & $1000^{c}$ & 2000 & 4 & $\mathrm{M}$ & 4.8 & 2919 & 1141 & 180 & 0.69 & 472 \\
\hline & & & & $\mathrm{F}$ & 3.6 & 2469 & 931 & 180 & 0.69 & 403 \\
\hline \multirow[t]{2}{*}{ Southern giant petrel } & $4000^{c}$ & 8000 & 19 & $\mathrm{M}$ & 5.1 & 3040 & 1199 & 280 & 0.69 & 757 \\
\hline & & & & $\mathrm{F}$ & 4.2 & 2714 & 1044 & 280 & 0.69 & 679 \\
\hline Antarctic prion & $48900^{\mathrm{C}}$ & 97800 & 7188 & Adults & 0.15 & 393 & 99 & 156 & 0.69 & 52 \\
\hline \multirow[t]{2}{*}{ Macquarie shag } & $768^{\mathrm{c}}$ & 1536 & 2 & $\mathrm{M}$ & 3.6 & 2905 & 1367 & 365 & 0.69 & 950 \\
\hline & & & & $\mathrm{F}$ & 2.6 & 2366 & 1113 & 365 & 0.69 & 773 \\
\hline Toothfish & - & - & 62473 & - & - & - & - & - & - & - \\
\hline
\end{tabular}

Johnstone (1977), Voisin \& Bester (1981), Weimerskirch et al. (1986, 1989), and Marchant \& Higgins (1990). Population and mass data on the Macquarie shag were derived from Brothers (1985) and Brothers (unpubl. data, in Scott 1994). The biomass of toothfish was based on estimates of the available abundance in mid-1995 (1 yr after the commencement of the fishery). The biomass of toothfish available to the fishery was estimated to be 62474 (95\% CI 17146 to 1002728 ) $t$ (Tuck et al. 1999). For the purpose of this study, where a range of estimates for the population size of species was available, the mid-point of such estimates were used to calculate their energy and food requirements (Table 1 ).

Diet data sources and prey grouping. Data on the diets of seals and seabirds were obtained from published and unpublished sources, and are summarised in Table 2. With the exception of the Antarctic prion and the species composition of the diet of blackbrowed albatrosses (although percentage biomass of main prey groups were derived from Macquarie Is- land), all diet information used in this study came from samples collected at Macquarie Island (Table 2). Dietary composition of all predators was expressed as percentage of wet prey mass. In cases where data were expressed by the numerical abundance of prey, they were converted to mass by multiplying the number of prey items by the estimated mass of the prey items consumed. Data on the composition of the commercial catch at Macquarie Island was based on the mean annual catch of toothfish and bycatch species over a 3 yr period (1996/97 to 1998/99) (Williams unpubl. data). Only major fish and invertebrate bycatch species were included. Corals and sponges were excluded.

Prey species were summarised into 35 groups based mostly on the lowest taxonomic level that could be identified from stomach or faecal data. For many diet studies the lowest taxonomic grouping of fish prey was to the family level (with the exception of toothfish), whereas for cephalopod prey this was generally to the genus level. However, where more detailed identification of fish prey to species level was available, this was 
Table 2. Details on the sources of diet information used in this study, and the type, number and timing when samples were collected. The form in which prey composition data were available (FM: frequency by mass; FN: frequency by number; FO: frequency of occurrence), and how data were converted to FM where needed, are also presented

\begin{tabular}{|c|c|c|c|c|c|c|}
\hline Species & Type of diet samples & No. and location & Year & Month & Data form & Source \\
\hline $\begin{array}{l}\text { Southern elephant } \\
\text { seal }\end{array}$ & $\begin{array}{l}\text { Stomach contents } \\
\text { from killed and } \\
\text { stomach flushed seals }\end{array}$ & 71-MI & $\begin{array}{l}1978-85 \\
1987-88 \\
1989-90\end{array}$ & $\begin{array}{l}\text { Spring \& } \\
\text { summer }\end{array}$ & $\begin{array}{l}\text { FM-squid } \\
\text { FN-fish }\end{array}$ & Green \& Burton (1993) \\
\hline $\begin{array}{l}\text { Antarctic fur seal, } \\
\text { subantarctic fur sea }\end{array}$ & $\begin{array}{l}\text { Faecal } \\
\text { al }\end{array}$ & 138-MI & $1990-91$ & Dec-Mar & $\begin{array}{l}\text { FN-fish, } \\
\text { FO-squid }^{\mathrm{a}, \mathrm{c}}\end{array}$ & $\begin{array}{l}\text { Goldsworthy et al. (1997); } \\
\text { Goldsworthy (unpubl. data) }\end{array}$ \\
\hline $\begin{array}{l}\text { New Zealand fur } \\
\text { seal }\end{array}$ & Faecal & 371-MI & $1988-89$ & Nov-Mar & $\begin{array}{l}\text { FN-fish } \\
\text { FO-squid, birds }{ }^{\mathrm{a}, \mathrm{d}}\end{array}$ & Green et al. (1990) \\
\hline King penguin & Stomach contents & 144-MI & $1984-85$ & Nov-Nov & FM & Hindell (1988a) \\
\hline Royal penguin & $\begin{array}{l}\text { Stomach contents } \\
\text { Stomach contents }\end{array}$ & $\begin{array}{l}\text { 258-MI } \\
\text { 304-MI }\end{array}$ & $\begin{array}{l}1984-85 \\
1993-96\end{array}$ & $\begin{array}{l}\text { Nov-Feb } \\
\text { Nov-Feb }\end{array}$ & $\begin{array}{l}\text { FM } \\
\text { FM }\end{array}$ & $\begin{array}{l}\text { Hindell }(1988 c) \\
\text { Hull }(1997,1999 b)\end{array}$ \\
\hline $\begin{array}{l}\text { Rockhopper } \\
\text { penguin }\end{array}$ & $\begin{array}{l}\text { Stomach contents } \\
\text { Stomach contents }\end{array}$ & $\begin{array}{l}\text { 104-MI } \\
\text { 236-MI }\end{array}$ & $\begin{array}{l}1984-85 \\
1984-85\end{array}$ & $\begin{array}{l}\text { Nov-Feb } \\
\text { Dec-Feb }\end{array}$ & $\begin{array}{l}\text { FM } \\
\text { FM }\end{array}$ & $\begin{array}{l}\text { Hindell }(1988 b) \\
\text { Hull }(1997,1999 b)\end{array}$ \\
\hline Gentoo penguin & $\begin{array}{l}\text { Stomach contents } \\
\text { Stomach contents }\end{array}$ & $\begin{array}{l}\text { 98-MI } \\
82-\mathrm{MI}\end{array}$ & $\begin{array}{l}1985 \\
1993-94\end{array}$ & $\begin{array}{l}\text { Apr-Nov } \\
\text { Oct-Jan }\end{array}$ & $\begin{array}{l}\text { FM } \\
\text { FM }\end{array}$ & $\begin{array}{l}\text { Hindell (1989) } \\
\text { Robinson \& Hindell (1996) }\end{array}$ \\
\hline $\begin{array}{l}\text { Black-browed } \\
\text { albatross }\end{array}$ & Regurgitations & Unknown-MI & 1997-99 & $\begin{array}{l}\text { Spring- } \\
\text { autumn }\end{array}$ & $\mathrm{FM}^{\mathrm{e}}$ & A. Terauds (pers. comm.) \\
\hline $\begin{array}{l}\text { Northern giant } \\
\text { petrel }\end{array}$ & Regurgitations & 341-MI & $\begin{array}{l}1969-70 \\
1970-71\end{array}$ & $\begin{array}{l}\text { Spring- } \\
\text { autumn }\end{array}$ & $\mathrm{FO}^{\mathrm{f}}$ & Johnstone (1977) \\
\hline $\begin{array}{l}\text { Southern giant } \\
\text { petrel }\end{array}$ & Regurgitations & 310-MI & $\begin{array}{l}1969-70 \\
1970-71\end{array}$ & $\begin{array}{l}\text { Spring- } \\
\text { autumn }\end{array}$ & $\mathrm{FO}^{\mathrm{f}}$ & Johnstone (1977) \\
\hline Antarctic prion & Regurgitations & $\begin{array}{l}\text { 90-South } \\
\text { Georgia }\end{array}$ & $1974-75$ & Dec-Mar & FM & $\begin{array}{l}\text { Prince (1980b) } \\
\text { Reid et al. (1997) }\end{array}$ \\
\hline Macquarie shag & Regurgitations & 77-MI & $1975-79$ & Dec-Feb & FM & Kato et al. (1996) \\
\hline Toothfish & Stomach contents & 1423-MI & 1995-99 & Nov-Mar & FM & Goldsworthy et al. (2001) \\
\hline Fishery & Commercial hauls & 839 hauls & $\begin{array}{l}1996 / 97- \\
1998 / 99\end{array}$ & Nov-Feb & $\mathrm{FM}^{\mathrm{g}}$ & Williams et al. (unpubl data) \\
\hline $\begin{array}{l}{ }^{\mathrm{a}} \text { Fish taxa numerical } \\
{ }^{\mathrm{b}} \text { Biomass contributio } \\
\text { Island southern eler } \\
{ }^{\mathrm{c}} \text { Estimated biomass } \\
{ }^{\mathrm{d}} \text { Estimated biomass } \\
{ }^{\mathrm{e}} \text { Estimates of fishes } \\
\text { comm.). Cephalopo } \\
\text { Fish component in } \mathrm{t} \\
{ }^{\mathrm{f}} \text { Study used to deter } \\
{ }^{\mathrm{g}} \text { Excluding corals an }\end{array}$ & $\begin{array}{l}1 \text { abundance (based on } \\
\text { on of cephalopods }\left(55^{\circ}\right. \\
\text { phant seals } \\
\text { contribution of fishes ( } 9 \\
\text { contribution of fishes ( } 8 \\
(15 \%) \text {, cephalopods ( } \\
\text { d prey species and thei } \\
\text { the diet based on Princ } \\
\text { rmine prey composition } \\
\text { d sponges }\end{array}$ & $\begin{array}{l}\text { the presence as o } \\
\%) \text { and fish }(45 \% \text {, } \\
95 \%) \text { and cephalo } \\
85 \%) \text {, cephalopod } \\
65 \%) \text {, crustacean } \\
\text { ir relative contribu } \\
\text { e 1980a) } \\
\text { Mass contributic }\end{array}$ & $\begin{array}{l}\text { toliths) con } \\
\text { at Macqu } \\
\text { opods ( } 5 \%) \\
\text { As ( } 5 \%) \text { and } \\
\text {, }(5 \%) \text { and } \\
\text { ution based } \\
\text { on of prey i }\end{array}$ & $\begin{array}{l}\text { verted to rel } \\
\text { arie Island } \\
\text { Goldsworth } \\
\text { birds }(10 \%) \\
\text { carrion }(15 \\
\text { on data fron } \\
\text { ems estimat }\end{array}$ & $\begin{array}{l}\text { ative biomass using } \\
\text { ased on the estimc } \\
\text { (Goldsworthy unp } \\
\text { \%) biomass in the } \\
\text { n Iles Kerguelen (C) } \\
\text { ed using prey biom }\end{array}$ & $\begin{array}{l}\text { g estimates of prey mass } \\
\text { late by Slip (1997) for Heard } \\
\text { oubl. data) } \\
\text { diet from A. Terauds (pers. } \\
\text { Cherel \& Weimerskirch 1995). } \\
\text { nass data in Hunter (1983) }\end{array}$ \\
\hline
\end{tabular}

used (e.g. for fur seals, penguins and the fishery). Diet composition was also summarised into 6 main ecological prey categories: pelagic fishes (Myctophidae, Bathylagidae, Paralepididae), demersal fishes (Nototheniidae, Harpagiferidae, Congiopodidae, Moridae, Macrouridae, Bothidae, Squalidae), cephalopods, pelagic crustaceans (euphausids, amphipods, copepods, and ostracods) and demersal crustaceans (prawns and crabs) and birds/carrion.

Diet overlaps. Diet overlaps between predators were examined using 2 methods. First, an overlap index was used to calculate diet similarities between 2 predators $(i$ and $j$ ). This index, termed percentage similarity index (\%PSI), was modified from Schoener (1970):

$$
{ }_{0 P S I}=100 \times\left(1.0-0.5 \sum_{h=1}^{s}\left|P_{h i}-P_{h j}\right|\right)
$$

where $P_{h i}$ is the proportion by mass of prey category $h$ in predator $i_{i} P_{h j}$ the proportion by mass of prey category $h$ in predator $j$, and $s$ is the number of prey categories. This method produces a similarity matrix for all predator pairs being compared.

The second method applied a hierarchical cluster analysis to diet data in order to classify predator species 
into distinct trophic guilds. The BrayCurtis dissimilarity coefficients were used along with the average linkage clustering algorithm using the software package PRIMER (Plymouth Marine Laboratory, UK). Significant trophic guilds were determined following the methods of Jaksic \& Medel (1990).

Energy requirements and foodconsumption estimates. The approach in this study was to estimate the daily energy requirements of individuals of each species while in the MI-EEZ based on estimates of activity and field metabolic rate (FMR). Daily energy requirements were then converted to food requirements by first transforming diet data (expressed as proportion of biomass) to proportions of total energy intake using estimates of the energy density of various prey taxa consumed (Table 3). Daily food requirements were then calculated as the sum of the product of the daily energy requirements and prey energy frequencies. The total annual energy requirements and consumption were then estimated by multiplying the daily estimates by total days that animals were estimated to be within the MI-EEZ.

For a particular seabird or fur seal species $i$, the energy requirements $e(\mathrm{~kJ})$ on Day $k$ for animals of a given age-class and/or gender were estimated using the following equation, modified from Croll \& Tershy (1998) (see Table 1):

$$
e_{i}^{k}=\frac{\left(F_{\mathrm{a}} P_{\mathrm{a}}\right)+\left(F_{\mathrm{r}} P_{\mathrm{r}}\right)}{M}
$$

where $F_{\mathrm{a}}$ is the field metabolic rate $(\mathrm{kJ})$ of animals at sea (active) and $F_{\mathrm{r}}$ is the metabolic rate when animals are ashore (resting). The proportion of time spent at sea and on-shore on any given day are given by $P_{\mathrm{a}}$ and $P_{\mathrm{r}}$, respectively, $M$ is the metabolic energy (assimilation efficiency), assumed to be 0.69 for petrels (Jackson 1986), and 0.74 for other species (Davis et al. 1989) (present Table 1). Metabolic rate $(F)$ values for fur seals were based on those determined for Antarctic fur seals at South Georgia (Costa et al. 1989). The active and resting metabolic rates for penguin and petrels were estimated from regression equations in Green \& Gales (1990) and Warham (1996), respectively. The metabolic rate for the Macquarie shag (Table 1) was estimated from allometric equations (Koteja 1991).

The total number of days spent within the MI-EEZ by each species, and the proportion of time spent at sea and on shore during the various stages of the courting, incubation, brooding, chick feeding, lactation and moulting periods were estimated from accounts of the species annual cycle, breeding and attendance patterns (Brothers 1985, Weimerskirch et al. 1986, 1992, Davis et al. 1989, Marchant \& Higgins 1990 and references therein, Hull 1997, Slip 1997 and pers. comm., Goldsworthy 1999 and unpubl. data). For royal, rockhopper and king penguins undergoing long incubation and pre-moulting foraging trips, most of the foraging was estimated to occur outside of the MI-EEZ (Hull et al. 1977, Hull 1999a, B. Wienecke pers. comm.). As such, the only foraging time included was that estimated to occur from the island to the edge of the MI-EEZ on leaving the island, and from the edge of the EEZ when returning to the island. Penguins were estimated to travel at an average horizontal speed of $3.6 \mathrm{~km} \mathrm{~h}^{-1}$, and to take about $4.3 \mathrm{~d}$ to travel $370 \mathrm{~km}$, assuming continuous swimming at that speed.

Average activity and attendance patterns relative to the mean laying or pupping dates, were used to estimate the daily activity (proportion of time ashore and at sea) of seabird pairs or lactating seals, respectively. However, as not all pairs or animals lay or pup on the same day, data on the timing and spread (standard deviation) of laying and pupping dates were used to calculate a normal distribution around their means. From these, the proportion of pairs or animals undertaking activities on the days either side of the means were calculated in order to provide a more realistic representation of the daily-energy expenditure and 
consumption patterns among populations of seabirds and seals.

The total annual energy requirements of predator $i$ $\left(E_{i}\right)$ was thus estimated as,

$$
E_{i}=\sum_{k=1}^{d} \sum_{\substack{\text { age sex } \\ \text { class }}} \sum_{i} e^{k}
$$

where $d$ is the number of days spent in the MI-EEZ each year by predator $i$.

The daily consumption $C_{i j}^{k}$ (tonnes), of prey species $j$ by predator $i$ was estimated as

$$
c_{i j}^{k}=e_{i}^{k} \frac{f_{i j}}{\sum_{j=1}^{s} f_{i j} d_{j}}
$$

where $f_{i j}$ is the proportion by mass of prey species $j$ in the diet of predator $i, d_{j}$ is the energy density $\left(\mathrm{kJ} \mathrm{kg}^{-1}\right)$ of prey species $j$, and $s$ is total number of prey taxa consumed. The total annual food consumption by predator $i, C_{i}$, was calculated as

$$
C_{i}=\sum_{k=1}^{d} \sum_{j=1}^{s} C_{i j}^{k}
$$

For seabirds, published estimates of the energy requirement or total mass provisioned to chicks by adults were used to calculate the total amount of food fed to chicks from hatching to fledging. For penguins this was estimated to be 119.0, 25.6, 18.0 and $43.8 \mathrm{~kg}$ prey mass from hatching to fledging per chick for king, royal, rockhopper and gentoo penguins, respectively (Green \& Gales 1990, Moore et al. 1998). For the Antarctic prion this was $0.49 \mathrm{~kg}$ per chick (Prince 1980b).

Estimates of the annual energy requirements of southern elephant seals within the MI-EEZ were based on estimates for elephant seals breeding at Heard Island (17 $200 \mathrm{MJ} \mathrm{seal}^{-1} \mathrm{yr}^{-1}$ : Slip 1997). The annual energy requirements for southern elephant seals at Macquarie Island ( $\left.E_{\mathrm{es}}^{\prime}\right)$ was estimated as follows:

$$
E_{\mathrm{es}}^{\prime}=E_{\mathrm{es}} N_{\mathrm{es}} \frac{D_{\mathrm{es}}}{365}
$$

where $N_{\mathrm{es}}$ is the estimated population size at Macquarie Island, $E_{\mathrm{es}}$ is the average annual energy requirements of an elephant seal (17200 MJ) and $D_{\text {es }}$ is the number of days spent by elephant seals in the MI-EEZ waters annually (excluding time hauled out on land).

Satellite and geolocation tracking of approximately 100 elephant seals (juveniles, adult females and males) from Macquarie Island has shown a similar pattern of seals traveling directly to and from the island from foraging grounds that are generally located well outside the MI-EEZ (Slip et al. 1994, Hindell et al. 1999, Bradshaw et al. 2001, J. van den Hoff pers. comm). As such, the only foraging time within the MI-EEZ was assumed to occur when seals were traveling to or from the island. For southern elephant seals, this occurs twice per year, once during the winter for juveniles or during the breeding season for adults, and once for moulting (all seals). Transit times across the MI-EEZ were based on satellite tracking data from 7 transits of 5 yr-old male elephant seals, which traveled on average $4.3 \mathrm{~km} \mathrm{~h}^{-1}$ $(\mathrm{SD}=1.2)$ (J. van den Hoff unpubl. data). Assuming such horizontal swimming speeds, elephant seals were estimated to travel the $370 \mathrm{~km}$ to the edge of the EEZ in $3.6 \mathrm{~d}$ (2.8 to 4.9) and hence spend a total of 14.4 (11.2 to 19.6) days in the MI-EEZ each year (Table 1).

The 2 annual haul-outs of southern elephant seals are very predictable in their timing, and for each age and sex-class (yearlings, 2 to 3 yr-olds, sub-adults, breeding males and breeding females) can be described by normal curves (Hindell \& Burton 1988, Slip 1997). The date of maximum haul-out for the moulting and non-moulting haul-out for the various age and sex-classes, and the standard deviation of these (Slip 1997) were used to estimate the number of seals from each gender and age-class in the MI-EEZ on any given day of the year. Total annual food consumption for southern elephants seals was calculated using Eqs (4) \& (5), the ratio of annual consumption per total biomass of the population was used to estimate the annual consumption per age and sex class, and from these the daily food consumption of these classes was calculated throughout the course of a year within the MI-EEZ.

The food consumption of toothfish was estimated using the multiple regression equation developed by Palomares \& Pauly (1989) to estimate the consumption per biomass $(Q / B)$ of marine fish populations:

$$
\begin{gathered}
\ln Q / B=-0.1775-0.2018 \ln W_{\infty}+0.6121 \ln T \\
+0.5156 \ln A+1.26 F
\end{gathered}
$$

where $Q / B$ is the daily food consumption by a fish population as a percentage of its biomass, $W_{\infty}$ is the mean asymptotic mass ( $\mathrm{g}$ ) of the fish, $T$ is the mean habitat temperature $\left({ }^{\circ} \mathrm{C}\right), A$ is the aspect ratio of the caudal fin of the fish species (as a measure of the average activity/and or metabolic rate of the fish), and $F$ is the food type ( 0 in carnivores, 1 in herbivores). The aspect ratio $\left(A=h^{2} / s\right)$ of the caudal fin is estimated using measurements of its height $(h)$ and surface area $(s)$. $W_{\infty}$ was estimated to be $139328 \mathrm{~g}$, the water temperature at $400 \mathrm{~m}$ depth at Macquarie Island is approximately $2.5^{\circ} \mathrm{C}$ (unpubl. CTD data: CSIRO Marine Research), and $A$ was estimated to be 1.09. The total annual food consumption, $C_{\mathrm{t}}$, of the toothfish population in the MI-EEZ was estimated as:

$$
C_{\mathrm{t}}=365 \bar{B}(Q / B)
$$


where $\bar{B}$ is the estimated biomass of the toothfish population. Consumption by toothfish on each prey taxon (j) was calculated by determining:

$$
C_{\mathrm{tj}}=f_{j} C_{\mathrm{t}}
$$

Sensitivity analysis. A single parameter analysis of sensitivity was undertaken to evaluate the relative importance of input parameters to estimates of annual relative consumption. Parameters examined include population size and metabolic rate, as other parameters such as residence times and predation rates would show the same response as adjusting population size. Each parameter was separately varied by $\pm 10 \%$ for the 5 major predators (royal, king, rockhopper penguins, elephant seals and toothfish) and consumption for each prey species were recalculated. The percentage sensitivity $\left(S_{p, i}\right)$ from the base model for parameter $p$ and predators $i$ was then calculated:

$$
S_{p, i}=\frac{100\left(R C_{p, i}^{\prime}-R C_{p, i}\right)}{R C_{p, i}}
$$

where $R C^{\prime}{ }_{p, i}$ is the recalculated relative consumption by predator $i$, with parameter $p$ being varied by $10 \%$, and $R C_{p, i}$ is relative consumption from the base model. Sensitivities $\left(S_{p, i}\right)>10 \%$ indicate high sensitivities, while $S_{p, i}<10 \%$ indicate low sensitivity. For example, an $S_{p, i}=5 \%$ means that a $10 \%$ change of input parameter $p$ for predator $i$ resulted in increasing the base model estimate of consumption for predator $i$ by $5 \%$.

\section{RESULTS}

\section{Diet composition}

The diet composition of the seals, seabirds, toothfish and the fishery around Macquarie Island, are presented in Tables 4 (35 prey groups), 5 (ecological prey groups) \& 6 (to genus and species level for penguins, fur seals and fishery). Pelagic fish (mostly myctophids), were the primary prey $(>50 \%)$ of fur seals, king, and royal penguins, while demersal fish (mostly notothenids were important in the diets of the Macquarie shag, gentoo penguin and toothfish. Other important fish genera were Bathylagidae $(20 \%$ by mass in the diet of toothfish) and Harpagiferidae (15\% by mass in the diet of Macquarie shags). Squid were a major component of the diets of southern elephant seals and black-browed albatrosses, and accounted for $32 \%$ of the diets in toothfish (Table 4). Squid accounted for $24 \%$ of the diet of northern giant petrels, $14 \%$ of the diet of gentoo penguins, and $11 \%$ of the diets of southern giant petrels, and were a minor component $(<5 \%)$ for all other species examined. Although
Moroteuthis (Onychoteuthidae) was the most widely consumed squid genus (10 of 14 species), it only accounted for $\leq 8 \%$ of the diet in all the predatory species. Three genera of squid were dominant as prey species, Kondakovia in elephant seals $(23 \%)$, and Todarodes (39\%) and Martialia (27\%) (family Ommastrephidae) in black-browed albatrosses. Gonatus (19\%) (family Gonatidae) was the main squid genus taken by toothfish. All predators, with the exception of the Macquarie shag, consumed some squid (i.e. $>2 \%$ ).

Pelagic crustaceans (mostly euphausids and copepods) were the main prey for Antarctic prions and rockhopper penguins $(>70 \%)$, and were also important in the diet of royal penguins $(37 \%)$. Demersal crustaceans (mostly prawns) accounted for $10 \%$ of the diet in toothfish. Carrion (mostly birds) accounted for most of the diet of northern (72\%) and southern giant petrels $(84 \%)$, and at sea, carrion accounted for $15 \%$ of the diet of black-browed albatrosses. About $10 \%$ of the diets of New Zealand fur seals were live birds, mostly Eudyptes spp. penguins.

\section{Dietary overlap}

The highest level of dietary overlap was among the 3 fur seal species ( $\geq 89 \%$ ) and between fur seals and king penguins $(\geq 87 \%$ ) (Table 7 ). There were also high levels $(>60 \%)$ of dietary overlap between royal and rockhopper penguins and between royal and king penguins (Table 7). Other major diet overlaps were between rockhopper penguins and Antarctic prions (>60\%), and between northern and southern giant petrels (both $>80 \%$ ). The levels of dietary overlap among other species were generally below $45 \%$ (Table 7 ). There was little dietary overlap between toothfish and other species, the greatest being with the gentoo penguin $(22 \%)$ and southern elephant seal (19\%) (Table 7). There was little dietary overlap with the commercial fishery, the greatest being with its target species, toothfish (4\%). Other than the commercial fishery, the only other predator that preyed on toothfish was the gentoo penguin; however, its occurrence in the diet was very low $(0.1 \%)$ (Table 4$)$.

Indices of dietary overlap were highly sensitive to the taxonomic resolution of prey species groups. For example, when mytophid fishes, a principal component of the diet of several seals and penguins (Table 4), were subdivided to genus or species level (Table 6), diet overlap between Antarctic fur seals and king penguins decreased from 95 to $4.1 \%$ (Table 8). This was because although both predators consumed myctophids, the Antarctic fur seal consumed mostly Electrona subaspera, while king penguins consumed $E$. carlsbergi and Krefftichthys anderssoni (Table 6). Sim- 
Table 4. Percentages of prey biomass for 35 prey groups in the diets of 14 marine predators and the fishery in the Macquarie Island EEZ. The 35 prey groups are further aggregated into 4 major groups: fishes, cephalopods, crustaceans, and birds/carrion (bottom of table)

\begin{tabular}{|c|c|c|c|c|c|c|c|c|c|c|c|c|c|c|c|}
\hline Prey groups & 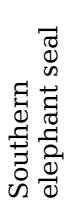 & 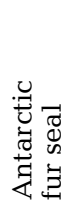 & 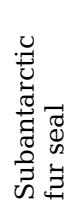 & 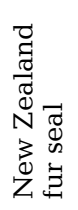 & 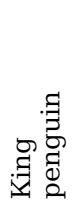 & 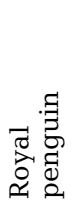 & 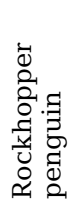 & 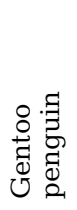 & 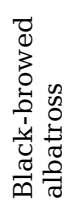 & 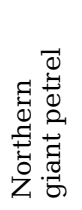 & 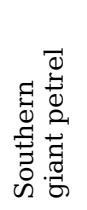 & 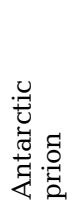 & 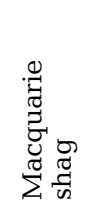 & 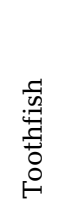 & 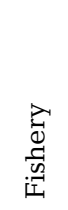 \\
\hline \multicolumn{16}{|l|}{ Fishes } \\
\hline Myctophids & 37.3 & 95.0 & 95.0 & 84.9 & 92.7 & 59.0 & 27.2 & 40.7 & 0 & 0 & 0 & 1.8 & 0 & 4.5 & 0 \\
\hline Bathylagus antarcticus & 7.7 & 0 & 0 & 0 & 0 & 0 & 0 & 0 & 0 & 0 & 0 & 0 & 0 & 19.5 & 0 \\
\hline Nototheniids & 0 & 0 & 0 & 0.1 & 0 & 0 & 0 & 2.6 & 15.0 & 2.0 & 1.0 & 0 & 85.1 & 12.1 & 0.1 \\
\hline Dissostichus eleginoides & 0 & 0 & 0 & 0 & 0 & 0 & 0 & 0.1 & 0 & 0 & 0 & 0 & 0 & 0 & 96.4 \\
\hline Harpagiferidae & 0 & 0 & 0 & 0 & 0 & 0 & 0 & 0.3 & 0 & 0 & 0 & 0 & 14.9 & 0 & 0 \\
\hline Congiopodidae & 0 & 0 & 0 & 0 & 0 & 0 & 0 & 9.0 & 0 & 0 & 0 & 0 & 0 & 0 & 0 \\
\hline Moridae & 0 & 0 & 0 & 0 & 0 & 0 & 0 & 0 & 0 & 0 & 0 & 0 & 0 & 6.7 & 0.5 \\
\hline Macrouridae & 0 & 0 & 0 & 0 & 0 & 0 & 0 & 0 & 0 & 0 & 0 & 0 & 0 & 10.6 & 2.7 \\
\hline Paralepididae & 0 & 0 & 0 & 0 & 5.0 & 0 & 0 & 0.2 & 0 & 0 & 0 & 0 & 0 & 0 & 0 \\
\hline Bothidae & 0 & 0 & 0 & 0 & 0 & 0 & 0 & 0 & 0 & 0 & 0 & 0 & 0 & 0.5 & 0 \\
\hline Shark & 0 & 0 & 0 & 0 & 0 & 0 & 0 & 0 & 0 & 0 & 0 & 0 & 0 & 4.2 & 0 \\
\hline \multicolumn{16}{|l|}{ Cephalopods } \\
\hline Alluroteuthis sp. & 4.4 & 0 & 0 & 0 & 0 & 0 & 0 & 0 & 0 & 0 & 0 & 0.6 & 0 & 0 & 0 \\
\hline Brachioteuthis sp. & 0.1 & 0 & 0 & 0 & 0 & 0 & 0 & 0 & 0 & 0 & 0 & 0 & 0 & 0 & 0 \\
\hline Chiroteuthis sp. & 0.2 & 0 & 0 & 0 & 0 & 0 & 0 & 0 & 0 & 0.8 & 0 & 0 & 0 & 1.9 & 0 \\
\hline Cirroteuthis sp. & 0 & 1.3 & 1.3 & 1.3 & 0 & 0 & 0 & 0 & 0 & 0 & 0 & 0 & 0 & 0.8 & 0 \\
\hline Galiteuthis sp. & 0.3 & 0 & 0 & 0 & 0 & 0 & 0 & 0 & 0 & 3.2 & 3.0 & 0 & 0 & 0.6 & 0 \\
\hline Gonatus antarcticus & 0.5 & 0 & 0 & 0 & 0 & 0 & 0 & 0 & 0 & 1.2 & 0 & 0 & 0 & 19.0 & 0 \\
\hline Histioteuthis sp. & 8.2 & 0 & 0 & 0 & 0 & 0 & 0 & 0 & 0 & 2.0 & 0 & 0 & 0 & 1.0 & 0 \\
\hline Kondakovia longimana & 23.4 & 0 & 0 & 0 & 0 & 0.2 & 0 & 0 & 0 & 0 & 2.0 & 0 & 0 & 0 & 0 \\
\hline Martialia sp. & 1.4 & 0 & 0 & 0 & 0.1 & 0.2 & 0.1 & 6.3 & 26.5 & 15.2 & 6.0 & 0 & 0 & 0 & 0 \\
\hline Mastigoteuthis sp. & 0 & 0 & 0 & 0 & 0 & 0 & 0 & 0 & 0 & 0.4 & 0 & 0 & 0 & 2.2 & 0 \\
\hline Moroteuthis sp. & 5.6 & 3.8 & 3.8 & 3.8 & 2.1 & 3.4 & 2.2 & 7.9 & 0 & 0.8 & 0 & 0 & 0 & 5.0 & 0 \\
\hline Octopoda & 0 & 0 & 0 & 0 & 0 & 0 & 0 & 0 & 0 & 0 & 0 & 0 & 0 & 0.8 & 0 \\
\hline Taonius sp. & 0 & 0 & 0 & 0 & 0 & 0 & 0 & 0 & 0 & 0.4 & 0 & 0 & 0 & 0.2 & 0 \\
\hline Todarodes sp. & 10.9 & 0 & 0 & 0 & 0 & 0.1 & 0 & 0 & 38.5 & 0 & 0 & 0 & 0 & 0 & 0 \\
\hline Vampryoteuthis sp. & 0 & 0 & 0 & 0 & 0 & 0 & 0 & 0 & 0 & 0 & 0 & 0 & 0 & 0 & 0 \\
\hline \multicolumn{16}{|l|}{ Crustaceans } \\
\hline Euphausids & 0 & 0 & 0 & 0 & 0 & 31.9 & 67.0 & 0 & 0 & 0 & 0 & 57.6 & 0 & 0 & 0 \\
\hline Prawns & 0 & 0 & 0 & 0 & 0 & 0 & 0 & 0 & 0 & 0 & 0 & 0 & 0 & 9.3 & 0 \\
\hline Crabs & 0 & 0 & 0 & 0 & 0 & 0 & 0 & 0 & 0 & 0 & 0 & 0 & 0 & 1.0 & 0.3 \\
\hline Amphipods & 0 & 0 & 0 & 0 & 0 & 5.2 & 3.4 & 0 & 0 & 0 & 0 & 8.1 & 0 & 0 & 0 \\
\hline Ostracods & 0 & 0 & 0 & 0 & 0 & 0 & 0 & 0 & 0 & 0 & 0 & 0 & 0 & 0 & 0 \\
\hline Copepods & 0 & 0 & 0 & 0 & 0 & 0 & 0 & 0 & 0 & 0 & 0 & 31.9 & 0 & 0 & 0 \\
\hline Others & 0 & 0 & 0 & 0 & 0 & 0 & 0 & 0 & 5.0 & 2.0 & 4.0 & 0 & 0 & 0 & 0 \\
\hline Birds & 0 & 0 & 0 & 10 & 0 & 0 & 0 & 0 & 0 & 0 & 0 & 0 & 0 & 0 & 0 \\
\hline Carrion & 0 & 0 & 0 & 0 & 0 & 0 & 0 & 0 & 15.0 & 72.0 & 84.0 & 0 & 0 & 0 & 0 \\
\hline Fishes & 45.0 & 95.0 & 95.0 & 85.0 & 97.8 & 59.0 & 27.2 & 85.9 & 15.0 & 2.0 & 1.0 & 1.8 & 100 & 58.1 & 99.7 \\
\hline Cephalopods & 55.0 & 5.0 & 5.0 & 5.0 & 2.2 & 3.9 & 2.4 & 14.1 & 65.0 & 24.0 & 11.0 & 0.6 & 0 & 31.6 & 0 \\
\hline Crustaceans & 0 & 0 & 0 & 0 & 0 & 37.1 & 70.3 & 0 & 5.0 & 2.0 & 4.0 & 97.6 & 0 & 10.3 & 0.3 \\
\hline Birds/carrion & 0 & 0 & 0 & 10 & 0 & 0 & 0 & 0 & 15.0 & 72.0 & 84.0 & 0 & 0 & 0 & 0 \\
\hline
\end{tabular}

ilarly, the overlap in diets of Antarctic fur seals with royal, rockhopper and gentoo penguins decreased from 63 to 7,30 to 5 and 21 to $8 \%$, respectively, when prey were grouped to genus or species levels (Table 8).

Cluster-analysis illustrated that, based on the 35 prey groups, the 14 marine predators and the fishery could be grouped into 7 significantly different trophic guilds (Fig. 2). These comprised: (1) a single-species guild containing the black-browed albatross, (2) a guild containing the giant petrels, (3) a large guild containing the fur seals, king penguin, gentoo penguin and southern elephant seal, (4) a guild including the royal and rockhopper penguin and Antarctic prion, 
Table 5. Percentages of prey biomass combined into 6 ecological prey groups, in the diets of 14 marine predators and the fishery in the Macquarie Island EEZ

\begin{tabular}{|c|c|c|c|c|c|c|c|c|c|c|c|c|c|c|c|}
\hline Prey group & 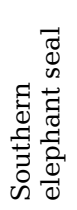 & 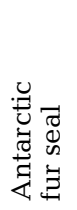 & 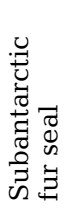 & 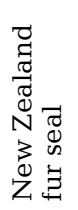 & 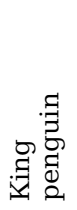 & 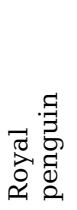 & 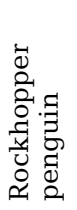 & 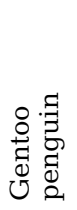 & 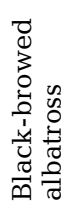 & 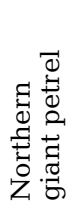 & 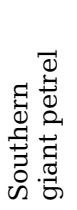 & 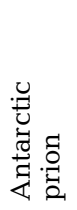 & 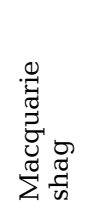 & 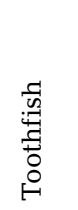 & 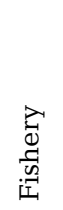 \\
\hline Pelagic fishes & 45.0 & 95.0 & 95.0 & 84.9 & 97.8 & 59.0 & 27.2 & 40.8 & 0.0 & 0.0 & 0.0 & 1.8 & 0.0 & 24.0 & 0.0 \\
\hline Demersal fishes & 0 & 0 & 0 & 0.1 & 0 & 0 & 0 & 45.0 & 15.0 & 2.0 & 1.0 & 0 & 100 & 34.2 & 99.7 \\
\hline Cephalopods & 55.0 & 5.0 & 5.0 & 5.0 & 2.2 & 3.9 & 2.4 & 14.1 & 65.0 & 24.0 & 11.0 & 0.6 & 0 & 31.6 & 0 \\
\hline Pelagic crustaceans & 0 & 0 & 0 & 0 & 0 & 37.1 & 70.3 & 0 & 5.0 & 2.0 & 4.0 & 97.6 & 0 & 0 & 0 \\
\hline Demersal crustaceans & 0 & 0 & 0 & 0 & 0 & 0 & 0 & 0 & 0 & 0 & 0 & 0 & 0 & 10.3 & 0.3 \\
\hline Birds and carrion & 0 & 0 & 0 & 10 & 0 & 0 & 0 & 0 & 15.0 & 72.0 & 84.0 & 0 & 0 & 0 & 0 \\
\hline
\end{tabular}

and single-species guilds containing the Macquarie shag (5), toothfish (6) and the fishery (7) (Fig. 2).

\section{Annual prey consumption within the MI-EEZ}

Estimates for the population sizes, biomasses, metabolic rates and the annual ER for the MI-EEZ are presented in Table 1. The estimated total annual consumption within the Macquarie Island EEZ by seals, seabirds, toothfish and the fishery is $419774 \mathrm{t}$ (Table 9). The majority of this is consumed by penguins $(88.4 \%)$, followed by toothfish $(7.6 \%)$ and seals $(3.1 \%)$. Petrels and Macquarie shags consumed only $0.8 \%$, and the commercial fishery $0.1 \%$ of the total prey biomass. Royal (51.5\%) and king (23.9\%) penguins consumed more than $75 \%$ of the total annual prey biomass. Of the total prey biomass consumed, $64 \%$ was fishes, $29 \%$ crustaceans and $7 \%$ cephalopods, with $<1 \%$ being seabirds or carrion (Table 9). Myctophids comprised most $(91 \%)$ of the fish prey biomass, with the next most important groups being bathylagids (3\%), nototheniids $(2 \%)$ and paralepidids $(2 \%)$ (Table 9). Euphausids (85\%) were the dominant crustacean prey by biomass, followed by amphipods $(11 \%)$ and prawns $(2 \%)$ (Table 9$)$. Of the cephalopod prey biomass, squid from the genus Moroteuthis
Table 6. Percentages of prey biomass in the diets of the major myctophid-consuming predators and the commercial fishery (including bycatch species) in the Macquarie Island EEZ. Taxonomic grouping of prey is to genus or species

\begin{tabular}{|c|c|c|c|c|c|c|c|c|}
\hline Prey species & 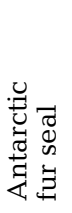 & 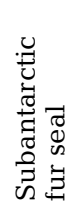 & 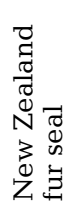 & 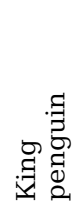 & 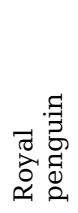 & 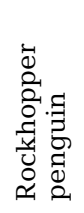 & 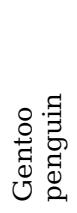 & 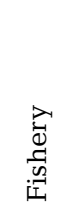 \\
\hline \multicolumn{9}{|l|}{ Fishes } \\
\hline Magnisudis prionosa & 0 & 0 & 0 & 4.5 & 0 & 0 & 0.2 & 0 \\
\hline Notolepis sp. & 0 & 0 & 0 & 0.5 & 0 & 0 & 0 & 0 \\
\hline Krefftichthys anderssoni & 0 & 0 & 4.0 & 38.0 & 51.8 & 23.2 & 9.2 & 0 \\
\hline Protomyctophum spp. & 0 & 0 & 0 & 0.9 & 0 & 0 & 0.4 & 0 \\
\hline Electrona antarctica & 0 & 0 & 0.1 & 0 & 0 & 0 & 0 & 0 \\
\hline E. carlsbergi & 1.6 & 0.2 & 0.5 & 53.6 & 4.8 & 2.8 & 15.0 & 0 \\
\hline E. subaspera & 92.0 & 86.7 & 55.1 & 0 & 2.4 & 1.3 & 1.2 & 0 \\
\hline Gymnoscopelus spp. & 1.3 & 8.1 & 25.3 & 0.3 & 0 & 0 & 14.7 & 0 \\
\hline Zanclorhynchus spinifer & 0 & 0 & 0 & 0 & 0 & 0 & 9.0 & 0 \\
\hline Harpagifer georgianus & 0 & 0 & 0 & 0 & 0 & 0 & 0.3 & 0 \\
\hline Macrourus carinatus & 0 & 0 & 0 & 0 & 0 & 0 & 0 & 1.5 \\
\hline Other macrourids & 0 & 0 & 0 & 0 & 0 & 0 & 0 & 1.1 \\
\hline Antimora rostrata & 0 & 0 & 0 & 0 & 0 & 0 & 0 & 0.3 \\
\hline Halargyreus johnsonii & 0 & 0 & 0 & 0 & 0 & 0 & 0 & 0.2 \\
\hline Dissostichus eleginoides & 0 & 0 & 0 & 0 & 0 & 0 & 0.1 & 96.4 \\
\hline Lepidonotothen squamifrons & $s 0$ & 0 & 0 & 0 & 0 & 0 & 11.1 & 0.1 \\
\hline Notothenia rossii & 0 & 0 & 0 & 0 & 0 & 0 & 1.0 & 0 \\
\hline Paranotothenia magellanica & 0 & 0 & 0.1 & 0 & 0 & 0 & 23.6 & 0 \\
\hline \multicolumn{9}{|l|}{ Cephalopods } \\
\hline Kondakovia longimana & 0 & 0 & 0 & 0 & 0.2 & 0 & 0 & 0 \\
\hline Martialia hyadesi & 0 & 0 & 0 & 0.1 & 0.2 & 0.1 & 6.3 & 0 \\
\hline Chiroteuthis spp. & 1.3 & 1.3 & 1.3 & 0 & 0 & 0 & 0 & 0 \\
\hline Moroteuthis spp. & 3.8 & 3.8 & 3.8 & 2.1 & 3.4 & 2.2 & 7.9 & 0 \\
\hline Todarodes spp. & 0 & 0 & 0 & 0 & 0.1 & 0 & 0 & 0 \\
\hline \multicolumn{9}{|l|}{ Crustaceans } \\
\hline Lithodes sp. & 0 & 0 & 0 & 0 & 0 & 0 & 0 & \\
\hline Euphausia spp. & 0 & 0 & 0 & 0 & 31.9 & 67.0 & 0 & 0 \\
\hline Themisto gaudichaudii & 0 & 0 & 0 & 0 & 5.2 & 3.4 & 0 & 0 \\
\hline Birds (Eudyptes sp.) & 0 & 0 & 10 & 0 & 0 & 0 & 0 & 0 \\
\hline
\end{tabular}

(44\%), Gonatus sp. (20\%) and Kondokvia sp. (11\%) were the most important prey species (Table 9). 
Table 7. Diet overlaps between 14 marine predators and the commercial fishery in the Macquarie Island EEZ based on the 35 prey groups presented in Table 4. Diet overlap is expressed as percentage similarity index (\%PSI)

\begin{tabular}{|c|c|c|c|c|c|c|c|c|c|c|c|c|c|c|}
\hline & 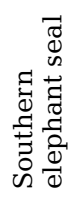 & 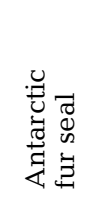 & 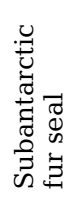 & 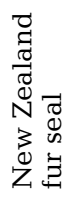 & r & 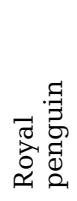 & 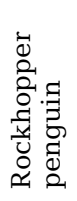 & 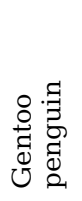 & 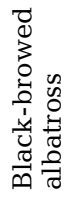 & 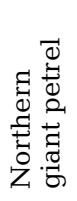 & 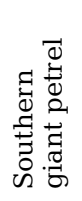 & 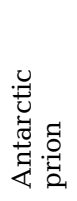 & 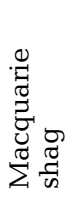 & 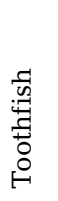 \\
\hline Antarctic fur seal & 41.0 & & & & & & & & & & & & & \\
\hline Subantarctic fur seal & 41.0 & 100 & & & & & & & & & & & & \\
\hline New Zealand fur seal & 41.0 & 89.9 & 89.9 & & & & & & & & & & & \\
\hline King penguin & 39.5 & 94.9 & 94.9 & 87.0 & & & & & & & & & & \\
\hline Royal penguin & 41.1 & 62.5 & 62.5 & 62.5 & 61.2 & & & & & & & & & \\
\hline Rockhopper penguin & 29.7 & 29.5 & 29.5 & 29.5 & 29.4 & 64.9 & & & & & & & & \\
\hline Gentoo penguin & 44.3 & 44.4 & 44.4 & 44.5 & 43.0 & 44.3 & 29.6 & & & & & & & \\
\hline Black-browed albatross & 12.4 & 0 & 0 & 0.1 & 0.1 & 0.3 & 0.1 & 21.3 & & & & & & \\
\hline Northern giant petrel & 5.2 & 0.8 & 0.8 & 0.9 & 0.9 & 1.0 & 0.9 & 9.1 & 34.2 & & & & & \\
\hline Southern giant petrel & 3.7 & 0 & 0 & 0.1 & 0.1 & 0.4 & 0.2 & 7.0 & 26.0 & 84.0 & & & & \\
\hline Antarctic prion & 2.4 & 1.8 & 1.8 & 1.8 & 1.8 & 38.9 & 62.8 & 1.8 & 0 & 0 & 0 & & & \\
\hline Macquarie shag & 0 & 0 & 0 & 0.1 & 0 & 0 & 0 & 36.0 & 15.0 & 2.0 & 1.0 & 0 & & \\
\hline Toothfish & 19.2 & 9.1 & 9.1 & 9.1 & 6.6 & 7.9 & 6.7 & 21.6 & 12.1 & 7.0 & 1.6 & 1.8 & 12.1 & \\
\hline Fishery & 0 & 0 & 0 & 0.1 & 0 & 0 & 0 & 0.2 & 0.1 & 0.1 & 0.1 & 0 & 0.1 & 3.6 \\
\hline
\end{tabular}

The sensitivity of the relative consumption ( $\%$ of total biomass consumed) by the 14 predators and the fishery to changes $( \pm 10 \%)$ in population and metabolic parameters are presented in Table 10. The results indicate that relative consumption of the predators and the fishery are generally insensitive to changes in these parameters, with most showing a change of $<5 \%$ from the base-model estimates. In general, the relative consumption was slightly more sensitive to changes in population parameters than in metabolic parameters (Table 10). Although the overall sensitivity is low, the results also show that the relative consumption of each predator is relatively sensitive to changes in those parameters associated with the same predator as compared to changes in those parameters associated with other

Table 8. Diet overlap between predators (fur seals and penguins) and the commercial fishery in the Macquarie Island EEZ based on taxonomic grouping to genus and species level as presented in Table 6. Diet overlap is expressed as percentage similarity index (\%PSI)

\begin{tabular}{|c|c|c|c|c|c|c|c|}
\hline & 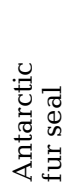 & 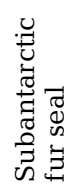 & 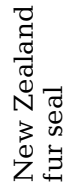 & 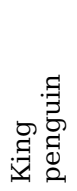 & 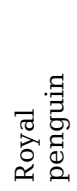 & 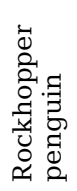 & 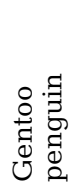 \\
\hline Subantarctic fur seal & 93.3 & & & & & & \\
\hline New Zealand fur seal & 62.0 & 68.4 & & & & & \\
\hline King penguin & 4.1 & 2.6 & 6.8 & & & & \\
\hline Royal penguin & 7.4 & 6.0 & 10.2 & 45.0 & & & \\
\hline Rockhopper penguin & 5.1 & 3.7 & 7.9 & 28.2 & 64.9 & & \\
\hline Gentoo penguin & 8.0 & 13.3 & 24.2 & 27.4 & 18.9 & 15.6 & \\
\hline Fishery & 0 & 0 & 0 & 0 & 0 & 0 & 0.1 \\
\hline
\end{tabular}

predators. For example, the relative consumption by elephant seals had the highest sensitivity to changes in elephant seal population estimates and metabolic rates, but not to changes in other parameters.

\section{Seasonal variation in consumption rates}

Seasonal variation in the estimated daily consumption rates of seals and seabirds feeding in the MI-EEZ are presented in Fig. 3. Although the daily consumption rates varied considerably among species, the seasonal trends were similar, with estimated consumption being greatest from October to March (Fig. 3). For many species (royal and rockhopper penguins, Antarctic fur seals and the petrels) daily consumption within the MI-EEZ was zero for part of the year (typically from May to September) when these species feed outside the MI-EEZ. However, when they return to the island in preparation for breeding in September and October, daily consumption rates increase rapidly (Fig. 3f). In the absence of any data on seasonal variation in the consumption rates of toothfish, daily consumption rates were assumed to be constant at about $108 \mathrm{t} \mathrm{d}^{-1}$. Total consumption within the MI-EEZ was lowest in August, when it averaged $176 \mathrm{t} \mathrm{d}^{-1}$, but increased steadily from September (381 t $\left.\mathrm{d}^{-1}\right)$ to January $\left(2779 \mathrm{t} \mathrm{d}^{-1}\right)$, and then declined rapidly through to March (1307 t d ${ }^{-1}$ ) (Fig. 3f). The average daily consumption in the MIEEZ from October to March was $1880 \mathrm{t} \mathrm{d}^{-1}$, 


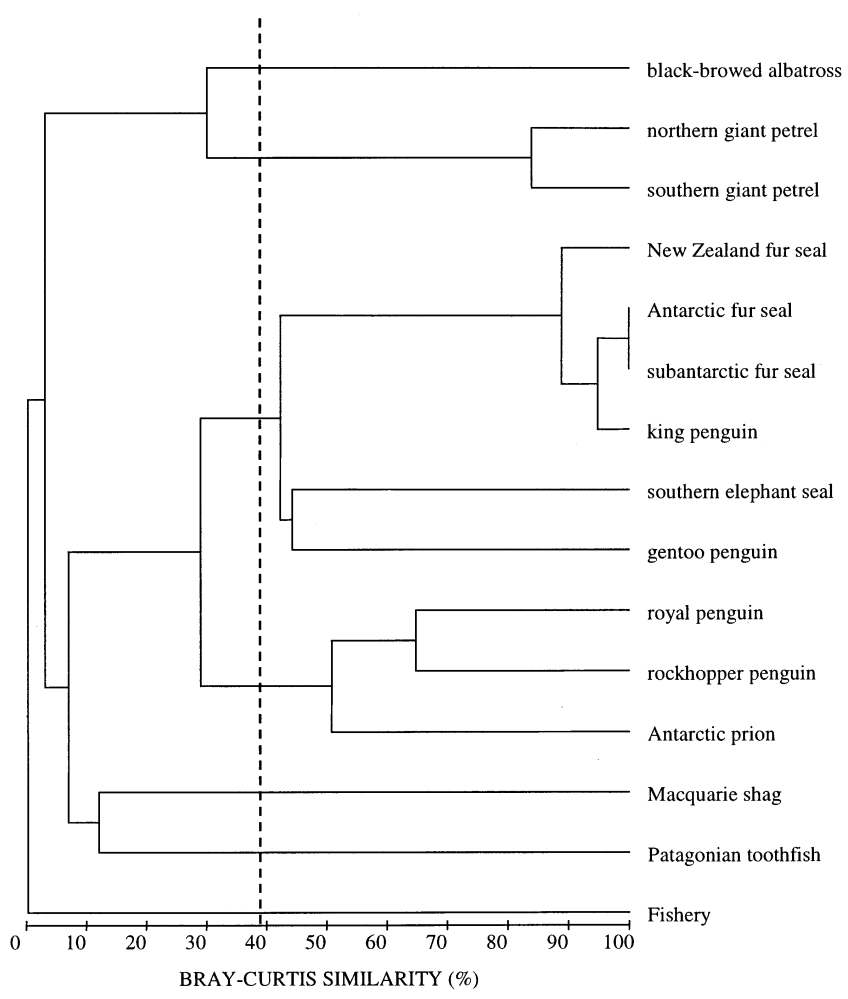

Fig. 2. Bray-Curtis similarity matrix of the diets of seabirds, seals, toothfish and the commercial fishery around Macquarie Island, based on the percentage contribution by mass of the 35 prey groups. Significant trophic guilds were determined following the methods of Jaksic \& Medel (1990), using 5000 randomisations. Dashed line at $38.9 \%$ diet similarity indicates that 7 trophic guilds are significant at $p<0.05$

peaking at $3045 \mathrm{t} \mathrm{d}^{-1}$ in late January (Fig. 3f). Daily consumption rates of fish (91\% myctophids) were lowest in August $\left(192 \mathrm{t} \mathrm{d}^{-1}\right)$, and highest in January (1646 t d ${ }^{-1}$ ) (Fig. 3f). Crustacean (85\% euphausids) and cephalopod consumption were also lowest in August (12 and $37 \mathrm{t} \mathrm{d}^{-1}$, respectively), and highest in January (981 and $146 \mathrm{t} \mathrm{d}^{-1}$, respectively) (Fig. 3f).

\section{DISCUSSION}

\section{Data limitations}

As with previous studies that have estimated the prey consumption of seals and seabirds, there are many inherent sources of error that must be considered when interpreting our results. These include uncertainties in population estimates, particularly for king, royal and rockhopper penguins, which are the major consumers of marine resources in the MI-EEZ. There are also large uncertainties in estimates of toothfish biomass at Macquarie Island, due to poor understanding of the spatial and temporal dynamics of the population (Tuck et al. 1999). Further, the estimates used here reflect the biomass available to the fishery and not the total biomass of toothfish in the region.

Much of the diet composition data used have come from studies that were only undertaken over a single season, and sometimes only for part of 1 season. Therefore, we have little understanding of the inter-annual and seasonal variability in the diets of most of the marine predators around Macquarie Island. Furthermore, the taxonomic resolution of prey species for some predators is poor, and as demonstrated here, can significantly bias diet-similarity analyses. There are also likely to be some errors in estimates of the energy requirements of seabirds and seals, as most of these were derived from allometric equations. Further, the calorific values for many of the prey species are unknown and were estimated from values of similar or closely related species.

Uncertainty in estimates of activity budgets (attendance patterns), and assumptions on how much time species spent feeding in the MI-EEZ are also potential sources of error. This may be particularly relevant for the southern elephant seal, for which we assumed that seals feed while in transit through the MI-EEZ between their main feeding grounds and haul-out sites on Macquarie Island. It is possible that the seals are feeding at a much lower rate (or possibly not at all) during these transits.

Because of scant demographic data on all the seabirds, and the unknown number of juveniles feeding within the EEZ at any time, all breeding pairs were assumed to breed annually (with the exception of king penguins) and successfully raise chicks, and all nonbreeding, pre-breeding and failed breeders were excluded. The assumption that all pairs breed successfully would inflate estimates of consumption, however the exclusion of non-breeding birds could decrease actual consumption estimates by up to $40 \%$ (Croxall et al. 1985). We could have made an estimate of the numbers of juveniles that may return to the island during the breeding season, but because we have no data on this, or the duration that these animals remain in the vicinity of Macquarie Island, we decided that it was better to omit them from our model. Our sensitivity analysis showed that relative consumption of predators and the fishery were generally insensitive to changes in population size, residence times and metabolic rates, with most showing a change of $<5 \%$ from the base-model estimates. As such, we believe that although the absolute estimates of consumption by predators may not be precise due to the uncertainties described, such errors are unlikely to alter the trophic relationships we have described among predators and the fishery.

One of the strengths of this study is that it has confined estimates of consumption to the period when ani- 
Table 9. Estimated annual prey consumption (t) of 14 marine predators and the commercial fishery in the Macquarie Island EEZ on the 35 prey groups, on 6 aggregated prey groups ('Aggregated groups'), and on all prey combined ('Combined prey')

\begin{tabular}{|c|c|c|c|c|c|c|c|c|c|c|c|c|c|c|c|c|}
\hline Prey species & 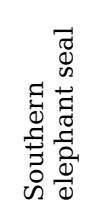 & 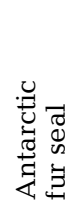 & 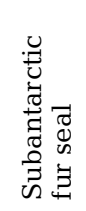 & 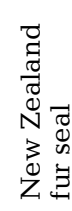 & 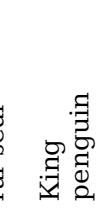 & 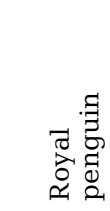 & 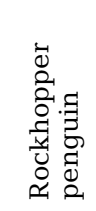 & 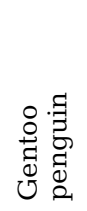 & 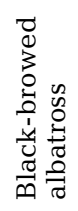 & 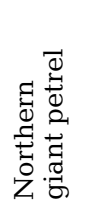 & 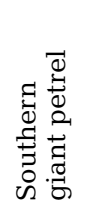 & 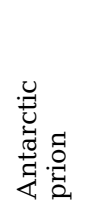 & 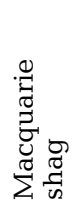 & 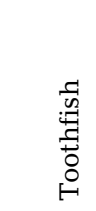 & $\begin{array}{l}\vec{D} \\
\stackrel{0}{0} \\
\frac{n}{n} \\
i=1\end{array}$ & $\underset{0}{\stackrel{\pi}{0}}$ \\
\hline \multicolumn{17}{|l|}{ Pelagic fishes } \\
\hline Paralepididae & 0 & 0 & 0 & 0 & 5059 & 0 & 0 & 6 & 0 & 0 & 0 & 0 & 0 & 0 & 0 & 5065 \\
\hline Myctophidae & 4486 & 151 & 75 & 610 & 93184 & 127657 & 13709 & 1564 & 0 & 0 & 0 & 25 & 0 & 1432 & 0 & 242891 \\
\hline \multicolumn{17}{|l|}{ Demersal fishes } \\
\hline Squalidae & 0 & 0 & 0 & 0 & 0 & 0 & 0 & 0 & 0 & 0 & 0 & 0 & 0 & 1357 & 0 & 1357 \\
\hline Macrouridae & 0 & 0 & 0 & 0 & 0 & 0 & 0 & 0 & 0 & 0 & 0 & 0 & 0 & 3401 & 15 & 3416 \\
\hline Moridae & 0 & 0 & 0 & 0 & 0 & 0 & 0 & 0 & 0 & 0 & 0 & 0 & 0 & 2149 & 3 & 2152 \\
\hline Congiopodidae & 0 & 0 & 0 & 0 & 0 & 0 & 0 & 345 & 0 & 0 & 0 & 0 & 0 & 0 & 0 & 345 \\
\hline Dissostichus eleginoide & 0 & 0 & 0 & 0 & 0 & 0 & 0 & 4 & 0 & 0 & 0 & 0 & 0 & 0 & 550 & 553 \\
\hline Other Nototheniidae & 0 & 0 & 0 & 1 & 0 & 0 & 0 & 1373 & 7 & 4 & 11 & 0 & 359 & 3884 & 1 & 5641 \\
\hline Bothidae & 0 & 0 & 0 & 0 & 0 & 0 & 0 & 0 & 0 & 0 & 0 & 0 & 0 & 170 & 0 & 170 \\
\hline \multicolumn{17}{|l|}{ Cephalopods } \\
\hline Alluroteuthis & 535 & 0 & 0 & 0 & 0 & 0 & 0 & 0 & 0 & 0 & 0 & 8 & 0 & 0 & 0 & 543 \\
\hline Brachioteuthis sp. & 7 & 0 & 0 & 0 & 0 & 0 & 0 & 0 & 0 & 0 & 0 & 0 & 0 & 0 & 0 & 7 \\
\hline Chiroteuthis sp. & 25 & 0 & 0 & 0 & 0 & 0 & 0 & 0 & 0 & 2 & 0 & 0 & 0 & 606 & 0 & 633 \\
\hline Cirroteuthis sp. & 0 & 2 & 1 & 9 & 0 & 0 & 0 & 0 & 0 & 0 & 0 & 0 & 0 & 271 & 0 & 282 \\
\hline Galiteuthis sp. & 36 & 0 & 0 & 0 & 0 & 0 & 0 & 0 & 0 & 7 & 34 & 0 & 0 & 195 & 0 & 272 \\
\hline Gonatus antarcticus & 58 & 0 & 0 & 0 & 0 & 0 & 0 & 0 & 0 & 3 & 0 & 0 & 0 & 6098 & 0 & 6158 \\
\hline Histioteuthis sp. & 981 & 0 & 0 & 0 & 0 & 0 & 0 & 0 & 0 & 4 & 0 & 0 & 0 & 317 & 0 & 1302 \\
\hline Kondakovia longimana & 2813 & 0 & 0 & 0 & 0 & 426 & 23 & 0 & 0 & 0 & 23 & 0 & 0 & 0 & 0 & 3285 \\
\hline Martialia sp. & 173 & 0 & 0 & 0 & 101 & 420 & 71 & 242 & 13 & 32 & 69 & 0 & 0 & 0 & 0 & 1121 \\
\hline Mastigoteuthis sp. & 0 & 0 & 0 & 0 & 0 & 0 & 0 & 0 & 0 & 1 & 0 & 0 & 0 & 707 & 0 & 708 \\
\hline Moroteuthis sp. & 677 & 6 & 3 & 27 & 2125 & 7423 & 1127 & 302 & 0 & 2 & 0 & 0 & 0 & 1618 & 0 & 13310 \\
\hline Taonius sp. & 0 & 0 & 0 & 0 & 0 & 0 & 0 & 0 & 0 & 1 & 0 & 0 & 0 & 71 & 0 & 72 \\
\hline Octopoda & 0 & 0 & 0 & 0 & 0 & 0 & 0 & 0 & 0 & 0 & 0 & 0 & 0 & 245 & 0 & 245 \\
\hline \multicolumn{17}{|l|}{ Crustaceans } \\
\hline Euphausids & 0 & 0 & 0 & 0 & 0 & 68895 & 33719 & 0 & 0 & 0 & 0 & 788 & 0 & 0 & 0 & 103402 \\
\hline Prawns & 0 & 0 & 0 & 0 & 0 & 0 & 0 & 0 & 0 & 0 & 0 & 0 & 0 & 2976 & 0 & 2976 \\
\hline Crabs & 0 & 0 & 0 & 0 & 0 & 0 & 0 & 0 & 0 & 0 & 0 & 0 & 0 & 328 & 2 & 330 \\
\hline Amphipods & 0 & 0 & 0 & 0 & 0 & 11353 & 1692 & 0 & 0 & 0 & 0 & 111 & 0 & 0 & 0 & 13156 \\
\hline Ostracods & 0 & 0 & 0 & 0 & 0 & 0 & 0 & 0 & 0 & 0 & 0 & 0 & 0 & 8 & 0 & 8 \\
\hline Copepods & 0 & 0 & 0 & 0 & 0 & 0 & 0 & 0 & 0 & 0 & 0 & 436 & 0 & 0 & 0 & 436 \\
\hline Others & 0 & 0 & 0 & 0 & 0 & 0 & 0 & 0 & 2 & 4 & 46 & 0 & 0 & 0 & 0 & 52 \\
\hline Birds & 0 & 0 & 0 & 0 & 72 & 0 & 0 & 0 & 0 & 0 & 0 & 0 & 0 & 0 & 0 & 72 \\
\hline Carrion & 0 & 0 & 0 & 0 & 0 & 0 & 0 & 0 & 0 & 7 & 152 & 961 & 0 & 0 & 0 & 1120 \\
\hline \multicolumn{17}{|l|}{ Aggregated groups } \\
\hline Pelagic fishes & 5418 & 151 & 75 & 610 & 98242 & 127657 & 13709 & 1569 & 0 & 0 & 0 & 25 & 0 & 7687 & 0 & 255143 \\
\hline Demersal fishes & 0 & 0 & 0 & 1 & 0 & 0 & 0 & 1728 & 7 & 4 & 11 & 0 & 395 & 10961 & 19 & 13126 \\
\hline Cephalopods & 6622 & 8 & 4 & 36 & 2226 & 8395 & 1221 & 544 & 32 & 51 & 126 & 8 & 0 & 10128 & 0 & 29400 \\
\hline Pelagic crustaceans & 0 & 0 & 0 & 0 & 0 & 80248 & 35411 & 0 & 2 & 4 & 46 & 1335 & 0 & 8 & 0 & 117054 \\
\hline Demersal crustaceans & 0 & 0 & 0 & 0 & 0 & 0 & 0 & 0 & 0 & 0 & 0 & 0 & 0 & 3304 & 2 & 3306 \\
\hline Bird and carrion & 0 & 0 & 0 & 72 & 0 & 0 & 0 & 0 & 7 & 152 & 961 & 0 & 0 & 0 & 0 & 1192 \\
\hline \multicolumn{17}{|l|}{ Combined prey } \\
\hline Total consumption & 12040 & 158 & 79 & 718 & 100468 & 216300 & 50341 & 3845 & 49 & 211 & 1144 & 1368 & 395 & 32088 & 570 & 419774 \\
\hline Total consumption (\%) & 2.87 & 0.04 & 0.02 & 0.17 & 23.93 & 51.53 & 11.99 & 0.92 & 0.01 & 0.05 & 0.27 & 0.33 & 0.09 & 7.64 & 0.14 & \\
\hline
\end{tabular}


Table 10. Sensitivities of relative consumption estimates of the 14 predators and the fishery to $10 \%$ changes in population size and metabolic rate estimates of the 5 main consumers of marine resources in the MI-EEZ used in this study

\begin{tabular}{|c|c|c|c|c|c|c|c|c|c|c|c|c|c|c|c|c|}
\hline \multirow{2}{*}{$\begin{array}{l}\text { Parameter } \\
\text { and } \\
\text { species }\end{array}$} & \multirow{2}{*}{$\begin{array}{c}\% \\
\text { change } \\
\text { in } \\
\text { para- } \\
\text { meter }\end{array}$} & \multicolumn{15}{|c|}{ Sensitivity - percentage (\%) change in consumption } \\
\hline & & 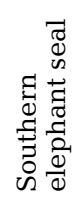 & 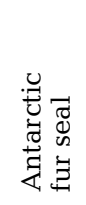 & 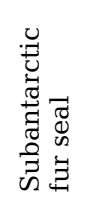 & 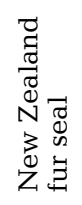 & 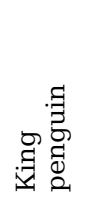 & 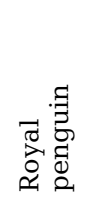 & 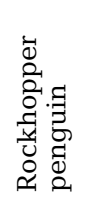 & 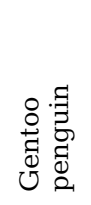 & 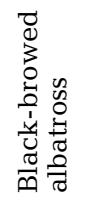 & 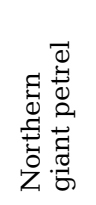 & 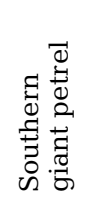 & 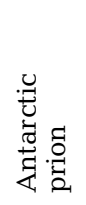 & 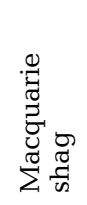 & 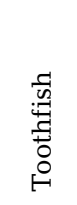 & 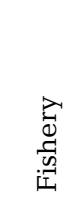 \\
\hline \multicolumn{17}{|l|}{ Population size } \\
\hline Southern & 10 & 9.7 & -0.3 & -0.3 & -0.3 & -0.3 & -0.3 & -0.3 & -0.3 & -0.3 & -0.3 & -0.3 & -0.3 & -0.3 & -0.3 & -0.3 \\
\hline elelpahnt seal & -10 & -9.7 & 0.3 & 0.3 & 0.3 & 0.3 & 0.3 & 0.3 & 0.3 & 0.3 & 0.3 & 0.3 & 0.3 & 0.3 & 0.3 & 0.3 \\
\hline \multirow[t]{2}{*}{ King penguin } & 10 & -2.3 & -2.3 & -2.3 & -2.3 & 7.4 & -2.3 & -2.3 & -2.3 & -2.3 & -2.3 & -2.3 & -2.3 & -2.3 & -2.3 & -2.3 \\
\hline & -10 & 2.5 & 2.5 & 2.5 & 2.5 & -7.8 & 2.5 & 2.5 & 2.5 & 2.5 & 2.5 & 2.5 & 2.5 & 2.5 & 2.5 & 2.5 \\
\hline \multirow[t]{2}{*}{ Royal penguin } & 10 & -4.9 & -4.9 & -4.9 & -4.9 & -4.9 & 4.6 & -4.9 & -4.9 & -4.9 & -4.9 & -4.9 & -4.9 & -4.9 & -4.9 & -4.9 \\
\hline & -10 & 5.4 & 5.4 & 5.4 & 5.4 & 5.4 & -5.1 & 5.4 & 5.4 & 5.4 & 5.4 & 5.4 & 5.4 & 5.4 & 5.4 & 5.4 \\
\hline \multirow{2}{*}{$\begin{array}{l}\text { Rockhopper } \\
\text { penguin }\end{array}$} & 10 & -1.2 & -1.2 & -1.2 & -1.2 & -1.2 & -1.2 & 8.7 & -1.2 & -1.2 & -1.2 & -1.2 & -1.2 & -1.2 & -1.2 & -1.2 \\
\hline & -10 & 1.2 & 1.2 & 1.2 & 1.2 & 1.2 & 1.2 & -8.9 & 1.2 & 1.2 & 1.2 & 1.2 & 1.2 & 1.2 & 1.2 & 1.2 \\
\hline \multirow[t]{2}{*}{ Toothfish } & 10 & -0.8 & -0.8 & -0.8 & -0.8 & -0.8 & -0.8 & -0.8 & -0.8 & -0.8 & -0.8 & -0.8 & -0.8 & -0.8 & 9.2 & -0.8 \\
\hline & -10 & 0.8 & 0.8 & 0.8 & 0.8 & 0.8 & 0.8 & 0.8 & 0.8 & 0.8 & 0.8 & 0.8 & 0.8 & 0.8 & -9.3 & 0.8 \\
\hline \multicolumn{17}{|l|}{ Metabolic rate } \\
\hline Southern & 10 & 9.7 & -0.3 & -0.3 & -0.3 & -0.3 & -0.3 & -0.3 & -0.3 & -0.3 & -0.3 & -0.3 & -0.3 & -0.3 & -0.3 & -0.3 \\
\hline elelpahnt seal & -10 & -9.7 & 0.3 & 0.3 & 0.3 & 0.3 & 0.3 & 0.3 & 0.3 & 0.3 & 0.3 & 0.3 & 0.3 & 0.3 & 0.3 & 0.3 \\
\hline \multirow[t]{2}{*}{ King penguin } & 10 & -2.0 & -2.0 & -2.0 & -2.0 & 6.5 & -2.0 & -2.0 & -2.0 & -2.0 & -2.0 & -2.0 & -2.0 & -2.0 & -2.0 & -2.0 \\
\hline & -10 & 2.1 & 2.1 & 2.1 & 2.1 & -6.8 & 2.1 & 2.1 & 2.1 & 2.1 & 2.1 & 2.1 & 2.1 & 2.1 & 2.1 & 2.1 \\
\hline \multirow[t]{2}{*}{ Royal penguin } & 10 & -4.4 & -4.4 & -4.4 & -4.4 & -4.4 & 4.2 & -4.4 & -4.4 & -4.4 & -4.4 & -4.4 & -4.4 & -4.4 & -4.4 & -4.4 \\
\hline & -10 & 4.9 & 4.9 & 4.9 & 4.9 & 4.9 & -4.6 & 4.9 & 4.9 & 4.9 & 4.9 & 4.9 & 4.9 & 4.9 & 4.9 & 4.9 \\
\hline \multirow{2}{*}{$\begin{array}{l}\text { Rockhopper } \\
\text { penguin }\end{array}$} & 10 & -1.1 & -1.1 & -1.1 & -1.1 & -1.1 & -1.1 & 7.8 & -1.1 & -1.1 & -1.1 & -1.1 & -1.1 & -1.1 & -1.1 & -1.1 \\
\hline & -10 & 1.1 & 1.1 & 1.1 & 1.1 & 1.1 & 1.1 & -7.9 & 1.1 & 1.1 & 1.1 & 1.1 & 1.1 & 1.1 & 1.1 & 1.1 \\
\hline \multirow[t]{2}{*}{ Toothfish } & 10 & -0.4 & -0.4 & -0.4 & -0.4 & -0.4 & -0.4 & -0.4 & -0.4 & -0.4 & -0.4 & -0.4 & -0.4 & -0.4 & 4.6 & -0.4 \\
\hline & -10 & 0.4 & 0.4 & 0.4 & 0.4 & 0.4 & 0.4 & 0.4 & 0.4 & 0.4 & 0.4 & 0.4 & 0.4 & 0.4 & -4.9 & 0.4 \\
\hline
\end{tabular}

mals actually feed within the MI-EEZ, where information on the diet was obtained. Most other studies that have estimated the consumption of marine resources in other parts of the Southern Ocean have typically extended estimates of consumption to outside the period when animals are feeding near breeding islands, where information on their diet and spatial distribution is generally lacking.

\section{Competition between commercial fisheries and other marine predators}

An approach to evaluating the extent of prey overlap and competition between seabirds and commercial fisheries was developed by Duffy \& Schneider (1994). Although developed specifically for seabirds, the model is also applicable to assessing competition between fisheries and marine mammals. It provides a hierarchical assessment of competition, based on ratios, specifically the 'Horn ratio' (that is the same as the \%PSI measure used in this study), 'Schaefer ratio', 'Evans ratio', 'Wiens ratio' and 'Bourne ratio' (Duffy \& Schneider 1994). Using this hierarchical approach, a decision is made on the extent of competition at each ratio test; if the competition is low at the first step ('Horn ratio'), then no further analysis is needed. However, if competition is high, then each successive ratio is tested in order to examine the extent and type of competition.

In the case of the toothfish fishery at Macquarie Island, we found the \%PSI (or Horn ratio) between the fishery and seabirds and seals to be very low $(0.1 \%$ for gentoo penguins, $\leq 0.1 \%$ for all other seals and seabirds, Tables $7 \&$ 8), indicating almost no direct overlap between prey species consumed by major marine predators and taken by the commercial fishery. The Schaefer ratio comparing the catch of toothfish by gentoo penguins and the fishery was also very low (0.007). The largest dietary overlap with the commercial fishery was with the target species, Patagonian toothfish, but even this was small $(<4 \%$, Table 7$)$. 

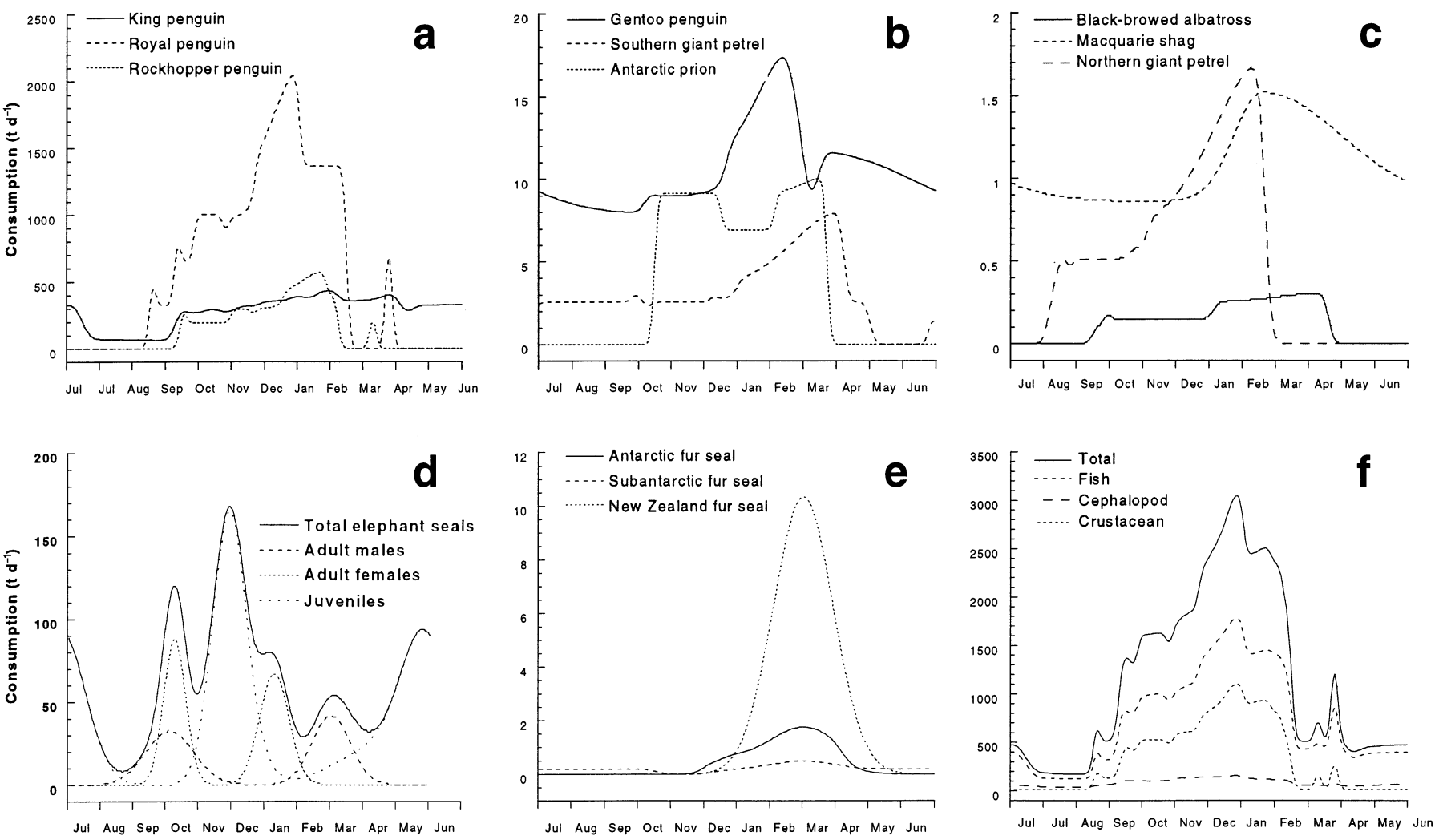

Fig 3. (a-e) Seasonal variation in the estimated daily consumption rates of marine resources by seabirds and seals within the MIEEZ; (f) estimated total daily consumption, and consumption of fish, crustaceans and cephalopods by seabirds, seals and toothfish within the MI-EEZ

The limited trophic interactions between toothfish, the fishery and seals and seabirds at Macquarie Island, primarily result from limited dietary overlap and the small percentage of total prey biomass consumed by toothfish and the fishery relative to that consumed by seabirds and seals. This is in marked contrast to the fishery for Antarctic krill in the south-west Atlantic, where there is nearly complete overlap in the diets of penguins, fur seals and the fishery, producing correspondingly high Horn and Schaefer ratios (Croll \& Tershy 1998).

A recent investigation into the diet of vagrant Hooker's sea-lions Phocarctos hookerii that haul-out periodically on Macquarie Island, found that toothfish are a common prey item (42\% frequency of occurrence in scats, McMahon et al. 1999). Hooker's sea lions have the greatest diving capacity of all otariid seals, and have been recorded to dive to about $500 \mathrm{~m}$ (Gales \& Mattlin 1997). However, as only 5 to 15 individuals of this species haul-out annually at Macquarie Island, their consumption is insignificant compared to that of other seals and seabirds that breed on the island. Although cetaceans were not considered in this study due to the paucity of data, sperm Physeter macro- cephalus and killer Orcinus orca whales have been reported taking toothfish from active fishing gear (Ashford et al. 1996), and sperm and southern bottlenose Hyperoodon planifrons whales (if the latter occur in the MI-EEZ) have the diving capacity to act as natural predators of toothfish (Solyanik \& Andriyashev 1964, Vukhov 1972, Hooker \& Baird 1999). Greenland sharks Somniosus microcephalus, which are occasionally caught as bycatch in the toothfish trawl fishery at Macquarie Island, may also be a natural predator of toothfish; however, examination of the stomach contents of 2 caught as bycatch revealed mostly macrourid and southern elephant seal remains (Williams unpubl. data).

The seal and seabird communities around Macquarie Island prey primarily on pelagic fish (myctophids) and pelagic crustaceans (94\% of prey biomass), neither of which form important prey of toothfish or are a target or bycatch of the commercial fishery. For this reason, the ecological impacts of the fishery on seals and seabirds are likely to be minimal, and may in fact bring about the competitive release of some pelagic fishes that could be consumed by seals and seabirds. More detailed ecological modelling would need to be under- 
taken to examine this possibility. Although the fishery for toothfish is unlikely to compete for the prey of seals and seabirds, the development of new fisheries in the future may do so. During the 1980s, approximately $75000 \mathrm{t}$ of the myctophid Electrona carlsbergi were taken from the south-western Atlantic and processed into meal and oil (Kock 1992). Interest in this fishery has increased in recent years, and in the 1999/2000 and 2000/2001 fishing season, the CCAMLR set a precautionary catch limit of $109000 \mathrm{t}$ for E. carlsbergi in the south-west Atlantic (CCAMLR Statistical Subarea 48.3: CCAMLR 2000). The rapid development of intensive aquaculture fisheries around the world has meant that the demand for fish-meal has been increasing, and as such it is possible that this fishery may expand to other areas in the Southern Ocean in the future. The estimated annual consumption of E. carlsbergi in the MIEEZ is about $66000 \mathrm{t}$, most of which is consumed by king penguins. If such a fishery were to be developed around Macquarie Island, it would compete directly with seabirds and seals and would need to be carefully managed.

\section{Diet overlaps between marine predators}

The greatest diet overlap among predators within the MI-EZZ was between the myctophid predators, especially among fur seals, between fur seals and king penguins, and among king, royal and rockhopper penguins. However, closer examination revealed that although the same myctophid species dominated in the diets of all 3 species of fur seal, the penguins (king, royal and rockhopper) consumed different myctophid species (Table 6) and, as such, the perceived high level of overlap was in fact much lower. This highlights how sensitive such analyses are to the taxonomic resolution of the prey species. The likely reason why fur seals take different myctophid species than penguins is that different species may be available near the surface at night when fur seals feed compared to during the day when penguins mostly feed (Robinson \& Hindell 1996, Goldsworthy et al. 1997, Hull 1997). The extent of dietary overlap between penguin species at Macquarie Island was much lower (16 to $65 \%$ ) than that reported between gentoo and macaroni penguins $(91 \%)$ at South Georgia, where crustaceans (mostly Euphausia superba) dominate in the diets of most seabirds (Croxall et al. 1997). With the exception of high levels of dietary overlap between northern and southern giant petrels and moderate overlap between Antarctic prions and rockhopper penguins, the diet overlap among other marine predators was generally low. In general, the extent of resource-partitioning among predators was high within the MI-EEZ relative to similar predator communities in the south-west Atlantic.
None of the seal or seabird species investigated had high diet overlaps with toothfish, the greatest overlap being with gentoo penguins $(22 \%)$ and southern elephant seals $(19 \%)$. The real extent to which gentoo penguins actually compete with toothfish for nototheniid fish (their common prey), is probably even lower than indicated by the similarity matrix, as gentoo penguins feed predominantly close inshore and in depths <150 m (Robinson \& Hindell 1996), while toothfish are found most abundantly at depths $>400 \mathrm{~m}$. Most of the competition between toothfish and southern elephant seals was for squid; however, the main squid species targeted by toothfish was Gonatus antarcticus, while for southern elephant seals at Macquarie Island this was Kondakovia longimana (Green \& Burton 1993, Goldsworthy et al. 2001) (present Table 4).

\section{Consumption of marine resources}

The total annual consumption of marine resources within the MI-EEZ by seals, seabirds, toothfish and the fishery was estimated to be $419774 \mathrm{t}$, with pelagic fishes, almost entirely myctophids, being the most important prey by biomass $(61 \%)$, followed by pelagic crustaceans $(30 \%)$ and cephalopods $(7 \%)$. Other prey categories, including demersal fishes and crustaceans and birds and carrion, were relatively minor contributors to the estimated annual prey consumption. The consumption of $419774 \mathrm{t}$ of prey per annum equates to a consumption of approximately $1010 \mathrm{~kg} \mathrm{~km} \mathrm{kr}^{-1}$ from within the MI-EEZ. However, there is likely to be considerable spatial heterogeneity in this consumption. The importance of fishes in diets of seabirds and seals at Macquarie Island is in marked contrast to many locations south of the Antarctic Polar Front, particularly in the south Atlantic Ocean, where the diets of most seabirds and seals are primarily pelagic crustaceans (Croxall et al. 1984, 1985, 1997, Croll \& Tershy 1998). At Heard Island just south of the Antarctic Polar Front in the southern Indian Ocean, seals and seabirds also consume mostly pelagic crustaceans $(60 \%)$, with smaller quantities of fishes $(32 \%)$ and squid (8\%) (Woehler \& Green 1992). Similar results have also been estimated for seabirds and seals at Iles Kerguelen (55\% crustacean, 30\% fish, 15\% cephalopod, Guinet et al. 1996).

Results from Macquarie Island are more similar to those found by Adams et al. (1993) at the Prince Edward Islands, also north of the Antarctic Polar Front, where consumption by 4 species of penguin was mostly of pelagic fishes at $70 \%$, with pelagic crustaceans only making up $18 \%$ and cephalopods $11 \%$ of total prey biomass. This compares with $65 \%$ pelagic fishes, $31 \%$ pelagic crustacean and $3 \%$ cephalopod of 
total prey biomass consumed by the 4 species of penguin at Macquarie Island. At Heard Island, demersal fish species occurred in more than $25 \%$ of dietary samples obtained from king, macaroni and gentoo penguins, in $14 \%$ of those from Antarctic fur seals, and accounted for most of the fish diet in southern elephant seals (Green et al. 1989, 1991, Woehler \& Green 1992, Green \& Burton 1993, Moore at al. 1998). This is in marked contrast to Macquarie Island, where demersal fishes were entirely absent from the diets of king and royal penguins, fur seals and the southern elephant seals, although they were present in gentoo penguins. Such differences in diets probably reflect the very large area of continental shelf on the Kerguelen Plateau available to marine predators around Heard Island compared to Macquarie Island.

The greatest consumers of marine resources within the MI-EEZ were penguins, which consumed about $88 \%$ of the total prey consumed by seabirds, seals and toothfish; $76 \%$ of this was consumed by royal and king penguins. Toothfish were estimated to consume $8 \%$ of the total prey biomass, and southern elephants seals $3 \%$, with the remaining species consuming $<1 \%$ of the total prey biomass each. Of the total prey biomass consumed by seabirds and seals around Macquarie Island, penguins consumed $96 \%$ (82\% by royal and king penguins). These results are similar to estimates for Heard Island and Iles Kerguelen, where seabird consumption (mostly penguins) makes up $81 \%$ and $89 \%$ of total seabird and seal consumption, respectively (Guinet et al. 1996, Woehler \& Green 1992). Similarly in the South Shetland Islands, consumption by chinstrap (Pygoscelis antarctica), Adelie ( $P$. adeliae) and gentoo penguins has been estimated to account for $99 \%$ of local seabird and seal consumption (Croll \& Tershy 1998).

The demand for marine resources by seabirds and seals around Macquarie Island was highly seasonal (Fig. 3). The greatest period of consumption was between October and March, peaking at over $3045 \mathrm{t} \mathrm{d}^{-1}$ in late January. This peak coincides with the period of greatest demand and competition for resources (from December to March), when most seabirds are feeding chicks, and fur seals are lactating. At this time, these species are dependant on prey biomass very near the island $(<200 \mathrm{~km})$, where they consume on average $2129 \mathrm{t}$ of prey per day. These daily consumption rates are similar to those reported for 4 penguin species breeding at the Prince Edward Islands, ranging from 1900 to $3300 \mathrm{t} \mathrm{d}^{-1}$ (Adams et al. 1993).

Estimates of consumption of the various prey groups presented here have assumed static population sizes of various predators. However, the populations of many of the species have changed markedly over the past $200 \mathrm{yr}$, and for some species large changes in population size may be expected in the near future. The indigenous population of fur seals was completely eliminated by sealers soon after the island's discovery in 1810, when approximately 193300 seals were killed, with fur seals only re-establishing a breeding population since the mid-1950s (Shaughnessy \& Fletcher 1987). Currently, the breeding population only numbers about 600 , with pup production increasing at a rate of about $13.9 \% \mathrm{yr}^{-1}$ (Goldsworthy et al. 1998). Unlike fur seals, the southern elephant seal population has recovered from sealing, but has recently declined to about half that of the estimated population size of the 1960s (Hindell \& Burton 1987). King and royal penguins were also taken for oil, but the current status of each species is not well known. The king penguin population is currently increasing, probably at 5 to $15 \%$ annually (E. Woehler pers. comm.). The royal penguin population has probably recovered from exploitation, and its population may still be increasing (Scott 1994). Changes in the population size of the various predators will affect the composition and quantity of marine resources consumed around Macquarie Island, and potentially alter the extent of inter-specific competition among predators. Such competition may affect the population sizes of some species and the recovery of others.

This study provides an initial assessment of the ecological linkages among marine predators and the commercial fishery within the MI-EEZ. Inevitably, data limitations, the exclusion of cetaceans, and potential errors in consumption estimates such as the unknown contribution of consumption within the MI-EEZ by non-breeding penguins, will lead to errors in estimates of the magnitude of trophic interaction. However, we believe that our main finding of weak trophic linkages between the commercial fishery and seabirds and seals, and between toothfish and other marine predators are unlikely to change. As more data are accumulated on population estimates, diet composition, predator foraging behavior, energy requirements and prey production, these uncertainties will be reduced. More accurate assessment of the ecological functions of toothfish, the commercial fishery, and other marine predators within the MI-EEZ will then be possible. This study provides an essential food-web model for the region on which further dynamic and integrated models can be developed to assist regional marine management.

Acknowledgements. Funding for this project was provided by the Fisheries Research and Development Corporation of Australia (FRDC Project 97/122). We thank David Slip, Karen Evans, John van den Hoff, Mark Hindell, Aleks Terauds, Robin Thomson and Eric Woehler for useful discussions on aspects of this study. We thank Barbera Weinecke, Eric Woehler, Cathy Bulman, and Jock Young for commenting on the manuscript. 


\section{LITERATURE CITED}

Abrams RW (1985) Energy and food requirements of pelagic aerial seabirds in different regions of the African sector of the Southern ocean. In: Siegfried WR, Condy PR, Laws RM (eds) Antarctic nutrient cycles and foodwebs. Proceedings of the Fourth SCAR Biology Symposium. Springer-Verlag, Berlin, p 466-472

Adams NJ, Moloney C, Navarro R (1993) Estimated food consumption by penguins at the Prince Edward Islands. Antarct Sci 5:245-252

Anderson DW, Gress F (1984) Brown pelicans and the anchovy fishery off southern California. In: Nettleship DN, Sanger A, Springer PF (eds) Marine birds: their feeding ecology and commercial fisheries relationships. Canadian Wildlife Service, Ottawa, p 128-135 (Spec Publ)

Ashford JR, Rubilar PS, Martin AR (1996) Interactions between cetaceans and longline fishery operations around South Georgia. Mar Mamm Sci 12:452-457

Barrat A (1976) Quelques aspects de la biologie et de l'ecologie du manchot royal (Aptenodytes patagonicus) des iles Crozet. Comite National Francais des Recherches Antarctiques 40:9-52

Boyd IL, Croxall JP, Lunn NJ, Reid K (1995) Population demography of Antarctic fur seals - the costs of reproduction and implications for life-histories. J Anim Ecol 64: 505-518

Bradshaw CJA, Hindell MA, Littnan C, Harcourt RG (2001) Determining marine movements of Australasian pinnipeds. In: Merrick JR, Archer M, Hickey G, Lee M (eds) Evolution and biogeography of Australasian vertebrates. Australian Scientific Publications, Sydney (in press)

Brothers NP (1984) Breeding, distribution and status of burrow-nesting petrels at Macquarie Island. Aust Wildl Res 11:113-131

Brothers NP (1985) Breeding biology, diet and morphometrics of the King shag, Phalacrocorax albiventer purpurascens, at Macquarie Island. Aust Wildl Res 12:81-94

Brown CR (1987) Energy requirements for growth and maintenance in macaroni and rockhopper penguins. Polar Biol 8:95-102

Brown CR (1989) Energy requirements and food consumption of Eudyptes penguins at the Prince Edward Islands. Antarct Sci 1:15-21

Burger AE, Cooper J (1984) The effects of fisheries on seabirds in South Africa and Namibia In: Nettleship DN, Sanger A, Springer PF (eds) Marine birds: their feeding ecology and commercial fisheries relationships Canadian Wildlife Service, Ottawa, p 150-161 (Spec Publ)

Butterworth DS, Duffy DC, Best PB, Bergh MO (1988) On the scientific basis for reducing the South African seal population. S Afr J Sci 84:179-188

CCAMLER (2000) Conservation measure 199/XIX Precautionary catch limit for Electrona carlsbergi in statistical subarea 48.3 in the 2000/01 season. In: Conservation measures and resolutions adopted at CCAMLR-XIX. CCAMLR, Hobart, Tasmania

Cherel Y, Weimerskirch H (1995) Sea birds as indicator of marine resources: black-browed albatrosses feeding on ommastrephid squids in Kerguelen waters. Mar Ecol Prog Ser 129:295-300

Clarke A, Clarke MR, Holmes LJ, Waters TD (1985) Calorific values and elemental analysis of eleven species of oceanic squid (Mollusca:Cephalopoda). J Mar Biol Assoc UK 65: 983-986

Copson GR, Rousevelle DE (1987) The abundance of royal penguins (Eudyptes schlegeli, Finsch) breeding at Mac- quarie Island. ANARE Res Notes (Aust Natl Antarct Res Exped) 41:1-11

Costa DP, Croxall JP, Duck C (1989) Foraging energetics of Antarctic fur seals, Arctocephalus gazella, in relation to changes in prey availability. Ecology 70:596-606

Croll DA, Tershy BR (1998) Penguins, fur seals, and fishing: prey requirements and potential competition in the South Shetland Islands, Antarctica. Polar Biol 19:365-374

Croxall JP, Prince PA (1982) A preliminary assessment of the impact of seabirds on the marine resources at South Georgia. Comite National Francais des Recherches Antarctiques 51:501-509

Croxall JP, Ricketts C, Prince PA (1984) Impact of seabirds on marine resources, chiefly krill, of South Georgia waters. In: Whittow GC, Rahn H (eds) Seabird energetics. Plenum Publishing Corporation, New York, p 285-317

Croxall JP, Prince PA, Ricketts C (1985) Relationships between prey life-cycles and the extent, nature and timing of seal and seabird predation in the Scotia Sea. In: Siegfried WR, Condy PR, and Laws RM (eds) Antartcic nutrient cycles and food webs. Springer-Verlag, Berlin, p 516-533

Croxall JP, Prince PA, Reid K (1997) Dietary segregation of krill-eating South Georgia seabirds. J Zool 242:531-556

Davies DH (1958) The South African pilchard (Sardinops ocellata) and maasbanker (Trachurus trachurus). The predation of sea-birds in the commercial fishery. Investig Rep Div Fish Un S Afr 31:1-16

Davis RW, Croxall JP, O'Connell MJ (1989) The reproductive energetics of gentoo (Pygoscelis papua) and macaroni (Eudyptes chrysolophus) penguins at South Georgia. J Anim Ecol 58:59-74

Duffy DC (1983) Environmental uncertainty and commercial fishing: effects on Peruvian guano birds. Biol Conserv 26: 227-238

Duffy DC, Schneider DC (1994) Sea bird-fishery interactions: a manager's guide. In: Nettleship DN, Buger J, Gochfeld M (eds) Seabirds on islands. Birdlife International, Cambridge (Birdlife Conserv Ser No 1), p 26-38

Furness RW (1984) Modelling relationships among fisheries, seabirds and marine mammals. In: Nettleship DN, Sanger A , Springer PF (eds) Marine birds: their feeding ecology and commercial fisheries relationships. Canadian Wildlife Service, Ottawa, p 117-126 (Spec Publ)

Furness RW, Cooper J (1982) Interactions between breeding seabirds and pelagic fish populations in the Southern Benguela Region. Mar Ecol Prog Ser 8:243-250

Gales NJ, Mattlin RH (1997) Summer diving behaviour of lactating New Zealand sea lions, Phocarctos hookeri. Can J Zool 75:1695-1706

Goldsworthy SD (1999) Maternal attendance behaviour of sympatrically breeding Antarctic and subantarctic fur seals, Arctocephalus spp., at Macquarie Island. Polar Biol 21:316-325

Goldsworthy SD, Hindell MA, Crowley HM (1997) Diet and diving behaviour of sympatric fur seals, Arctocephalus gazella and A. tropicalis, at Macquarie Island. In: Hindell MA, Kemper C (eds) Marine mammal research in the Southern Hemisphere. Vol. 1. Status, ecology and medicine. Surrey Beatty and Sons, Chipping Norton, p 151-63

Goldsworthy SD, Wynen L, Robinson S, Shaughnessy PD (1998) The population status and hybridisation of three sympatric fur seals (Arctocephalus spp.) at Macquarie Island. N Z Nat Sci 23 (Suppl):68

Goldsworthy SD, Williams R, Lewis M, Van den Hoff J, Young J, He X (2001) Diets of the Patagonian toothfish (Dissostichus eleganoides) around Macquarie Island. Mar Freshw Res (in press) 
Green K, Burton HR (1993) Comparison of the stomach contents of southern elephant seals, Mirounga leonina, at Macquarie and Heard Islands. Mar Mamm Sci 9:10-22

Green B, Gales RP (1990) Water, sodium, and energy turnover in free-living penguins. In: Davis LS, Darby JT (eds) Penguin biology. Acedemic Press, San Diego, p 245-268

Green K, Burton HR, Williams R (1989) Diet of Antarctic fur seals Arctocephalus gazella during the breeding season at Head Island. Antarct Sci 1:317-24

Green K, Williams R, Handasyde KA, Burton HR, Shaughnessy PD (1990) Interspecific and intraspecific diets of fur seals Arctocephalus species (Pinnipedia: Otariidea), at Macquarie Island. Aust Mammal 13:193-200

Green K, Burton HR, Williams R (1991) The diet of Antarctic fur seals during the late autumn and early winter around Head Island. Antarct Sci 3:359-361

Green K, Slip DJ, Moore GJ (1998) The take of fish species by seabirds and marine mammals in the Australian fisheries zone around Heard Island: the potential for competition with a commercial fishery. Polar Biol 20:273-280

Guinet C, Cherel Y, Ridoux V, Jouventin P (1996) Consumption of marine resources by seabirds and seals in Crozet and Kerguelen waters: changes in relation to consumer biomass 1962-85. Antarct Sci 8:23-30

Hammill MO, Lydersen CL, Kovacs KM, Sjare B (1997) Estimated fish consumption by hooded seals (Cystophora cristata), in the Gulf of St Lawence. J Northwest Atl Fish Sci 22:249-258

Hindell MA (1988a) The diet of the king penguin Aptenodytes patagonicus at Macquarie Island. Ibis 130:193-203

Hindell MA (1988b) The diet of the rockhopper penguin Eudyptes chrysocome at Macquarie Island. Emu 88:227-233

Hindell MA (1988c) The diet of the royal penguin Eudyptes schlegeli at Macquarie Island. Emu 88:219-226

Hindell MA (1989) The diet of the gentoo penguin Pygoscelis papua at Macquarie Island: winter and early breeding season. Emu 89:71-78

Hindell MA, Burton HR (1987) Past and present status of the southern elephant seal (Mirounga leonina) at Macquarie Island. J Zool 213:365380

Hindell MA, Burton HR (1988) Seasonal haul-out patterns of the southern elephant seal (Mirounga leonina) at Macquarie Island. J Mammal 69:81-88

Hindell MA, Mcconnell BJ, Fedak MA, Slip DJ, Burton HR, Reijnders HR, Mcmahon CR (1999) Environmental and physiological determinants of successful foraging by naive southern elephant seal pups during their first trip to sea. Can J Zool 77:1807-1821

Hooker SK, Baird RW (1999) Deep-diving behaviour of the northern bottlenose whale, Hyperoodon ampullatus (Cetacea: Ziphiidae). Proc R Soc Lond Ser B Biol Sci 266: 671-676

Hull CL (1997) The comparative foraging ecology of Royal Eudyptes schlegeli and Rockhopper E. chrysocome penguins. PhD thesis, University of Tasmania

Hull CL (1999a) Comparison of the diets of breeding royal (Eudyptes schlegeli) and rockhopper (Eudyptes chrysocome) penguins on Macquarie Island over three years. J Zool 247:507-529

Hull CL (1999b) The foraging zones of breeding royal (Eudyptes schlegeli) and rockhopper (E. chrysocome) penguins: an assessment of techniques and species comparisons. Wildl Res 26:789-803

Hull CL, Hindell MA, Michael K (1997) Foraging zones of royal penguins during the breeding season, and their association with oceanographic features. Mar Ecol Prog Ser 153:217-228
Hunt JR (1985) A preliminary comparison of marine bird biomass and food consumption between the south eastern Bering Sea and parts of the Southern Ocean. In: Siegfried WR Condy PR, Laws RM (eds) Antartcic nutrient cycles and food webs. Springer-Verlag, Berlin, p 487-492

Hunter S (1983) The food and feeding ecology of the giant petrels Macronectes halli and M. giganteus at South Georgia. J Zool 203:521-38

Ichii T, Naganobu N, Ogishima T (1996) Competition between the krill fishery and penguins in the South Shetland Islands. Polar Biol 16:63-70

Jackson S (1986) Assimilation efficiencies of White-chinned Petrels (Procellaria aequinoctialis) fed different prey. Comp Biochem Physiol 85A:301-303

Jaksic FM, Medel RG (1990) Objective recognition of guilds: testing for statistically significant species clusters. Oecologia 82:87-92

Johnstone GW (1977) Comparative feeding ecology of the giant petrels Macronectes giganteus (Gmelin) and M. halli (Mathews). In: Llana GA (ed) Adaptations within Antarctic ecosystems. Proceedings of the Third SCAR Symposium on Antarctic Biology. Gulf Publishing Company, Houston, p 647-668

Kato A, Nishiumi I, Naito Y (1996) Sex differences in the diet of King Cormorants at Macquarie Island. Polar Biol 16:75-77

Kock KH (1992) Antarctic fish and fisheries. Cambridge University Press, Cambridge

Koteja P (1991) On the relation between basal and field metabolic rates in birds and mammals. Funct Ecol 5:56-64

Marchant S, Higgins PJ (1990) Handbook of Australian, New Zealand and Antarctic birds, Vol 1A. Oxford University Press, Melbourne

Matthews JP (1961) The pilchard of South-West Africa (Sardinops ocellata) and maasbanker (Trachurus trachurus): bird predators, 1957-1958. Res Lab SW Afr Invest Rep Mar 3:1-35

McCann TS (1985) Size, status and demography of southern elephant seal (Mirounga leonina) populations. In: Ling JK, Bryden MM (eds) Sea mammals in south latitudes. Proceedings of a Symposium of the 52nd ANZAAS Congress. South Australian Museum, Adelaide, p 1-17

McMahon CR, Holly D, Robinson S (1999) The diet of itinerant male Hooker's sea lions, Phocartos hookeri, at subAntarctic Macquarie Island. Wildl Res 26:839-846

Moore GJ, Robertson G, Wieneke B (1998) Food requirements of breeding king penguins at Heard Island and potential overlap with commercial fisheries. Polar Biol 20:293-302

Palomares ML, Pauly D (1989) A multiple regression model for predicting the food consumption of marine fish populations. Aust J Mar Freshw Res 40:259-273

Prince PA (1980a) The food and feeding ecology of grey-headed albtross Diomedea chrysostoma and black-browed albatross D. melanophris. Ibis 122:476-488

Prince PA (1980b) The food and feeding ecology of blue petrel (Halobaena caerulea) and Dove prion (Pachyptila desolata). J Zool 190:59-76

Reid K, Croxall JP, Edwards TM (1997) Interannual variation in the diet of the Antarctic Prion Pachyptila desolata at South Georgia. Emu 97:126-132

Reilly PN, Kerle JA (1981) A study of the gentoo penguin Pygoscelis papua. Notornis 28:189-202

Robinson SA, Hindell MA (1996) Foraging ecology of gentoo penguins Pygoscelis papua at Macquarie Island during the period of chick care. Ibis 138:722-731

Robinson SA, Scott JJ (1999) Marine conservation at Macquarie Island. Tasmanian Parks and Wildlife Service, Hobart 
Rounsevell DE, Brothers NP (1984) The status and conservation of seabirds at Macquarie Island. In: Croxall JP, Evans PGH, Schreiber RW (eds) Status and conservation of the world's seabirds. International Council for Bird Preservation (ICBP) Cambridge, Tech Publ Nr. 2, p 587-292

Schoener TW (1970) Non-synchronous spatial overlap of lizards in patchy habitats. Ecology 51:408-418

Scott JJ (1994) Marine conservation at Macquarie Island. Tasmanian Parks and Wildlife Service and Ocean Rescue, Hobart

Shaughnessy PD, Fletcher D (1987) Fur seals, Arctocephalus spp. at Macquarie Island. In: Croxall JP, Gentry RL (eds) Status, biology and ecology of fur seals. Proceedings of an International Symposium and Workshop. NOAA Tech Rep NMFS 51, Cambridge, p 177-188

Slip DJ (1997) Foraging ecology of southern elephant seals from Heard Island. PhD thesis, University of Tasmania

Slip DJ, Hindell MA, Burton HR (1994) Diving behaviour of elephant seals from Macquarie Island: an overview. In: Le Boeuf BJ, Laws RM (eds) Elephant seals: population ecology, behavior, and physiology. University of California Press, Berkeley, p 253-270

Solyanik GA, Andriyashev AP (1964) An interesting ichthyological discovery. Large fish in the Antarctic. Soviet Antarctic Exploratin Information Bulletin 4(6):385

Stenson GB, Hammill MO, Lawson JW (1997) Predation by harp seals in Atlantic Canada: preliminary consumption estimates for Artcic cod, capelin and Atlantic cod. J Northwest Atl Fish Sci 22:137-154

Trites AW, Christensen V, Pauly D (1997) Competition between fisheries and marine mammals for prey and primary production in the Pacific Ocean. J Northwest Atl Fish Sci 22: $173-187$

Tuck GN, Williams R, Smith ADM, He X, Constable A (1999)

Editorial responsibility: Otto Kinne (Editor),

Oldendorf/Luhe, Germany
Abundance of Patagonian toothfish (Dissostichus eleginoides) at Macquarie Island estimated from tagging studies: 1995-1999. Working paper presented to the Subantarctic Fisheries Assessment Group, Hobart, Australia, SAFAG/7/3

Voisin JF, Bester MN (1981) The specific status of giant petrels Macronectes at Gough Island. In: Cooper J (ed) Proceedings of the Symposium on Birds of the Sea and Shore. African Seabird Group, Cape Town, p 215-22

Vukhov VL (1972) The range of fish of the genus Dissostichus (fam. Nototheniidae) in Antarctic waters of the Indian Ocean. J Ichthyol 12:346-347

Warham J (1963) The rockhopper penguin, Eudyptes chrysocome, at Macquarie Island. Auk 80:229-256

Warham J (1996) The behaviour, population biology and physiology of the petrels. Academic Press, London

Weimerskirch H, Jouventin P, Stahl JC (1986) Comparative ecology of the six albatross species on the Crozet Islands. Ibis 128:195-213

Weimerskirch H, Zotier H, Jouventin P (1989) The avifauna of the Kerguelen Islands. Emu 89:15-29

Weimerskirch H, Stahl JC, Jouventin P (1992) The breeding biology and population dynamics of king penguins Aptenodytes patagonica on the Crozet Islands. Ibis 134: $107-117$

Woehler EJ, Green K (1992) Consumption of marine resources by seabirds and seal at Heard Island and the McDonald Islands. Polar Biol 12:659-665

York A (1987) Northern fur seal, Callorhinus ursinus, Eastern Pacific population (Pribilof Islands, Alaska, and San Miguel, Island California). In: Croxall JP, Gentry RL (eds) Status, biology and ecology of fur seals. Proceedings of an International Symposium and Workshop. NOAA Tech Rep NMFS 51, Cambridge, p 9-21

Submitted: November 30, 1999; Accepted: October 26, 2000 Proofs received from author(s): August 2, 2001 